Florida International University FIU Digital Commons

3-19-2013

\title{
The Broken Mirror: Maternal Agency and Identity in Charles Dickens's Bleak House
}

Sarah E. Cash

Florida International University, scash005@fiu.edu

DOI: $10.25148 /$ etd.FI13042206

Follow this and additional works at: https://digitalcommons.fiu.edu/etd

\section{Recommended Citation}

Cash, Sarah E., "The Broken Mirror: Maternal Agency and Identity in Charles Dickens's Bleak House" (2013). FIU Electronic Theses and Dissertations. 828.

https://digitalcommons.fiu.edu/etd/828

This work is brought to you for free and open access by the University Graduate School at FIU Digital Commons. It has been accepted for inclusion in FIU Electronic Theses and Dissertations by an authorized administrator of FIU Digital Commons. For more information, please contact dcc@fiu.edu. 


\section{FLORIDA INTERNATIONAL UNIVERSITY}

Miami, Florida

THE BROKEN MIRROR:

MATERNAL AGENCY AND IDENTITY

IN CHARLES DICKENS'S BLEAK HOUSE

A thesis submitted in partial fulfillment of the

requirements for the degree of

MASTER OF ARTS

in

ENGLISH

by

Sarah Elizabeth Cash

2013 
To: Dean Kenneth G. Furton

College of Arts and Sciences

This thesis, written by Sarah Elizabeth Cash, and entitled The Broken Mirror: Maternal Agency and Identity in Charles Dickens's Bleak House, having been approved in respect to style and intellectual content, is referred to you for judgment.

We have read this thesis and recommend that it be approved.

Ana Luszczynska

Heidi Scott

Meri-Jane Rochelson, Major Professor

Date of Defense: March 19, 2013

The thesis of Sarah Elizabeth Cash is approved.

Dean Kenneth G. Furton

College of Arts and Sciences

Dean Lakshmi N. Reddi

University Graduate School

Florida International University, 2013 


\section{DEDICATION}

This thesis is dedicated to my husband, Gary Aaron Cash, for his help, love and support. 


\section{ACKNOWLEDGMENTS}

I wish to thank the members of my committee for their support. I wish to particularly thank Dr. Heidi Scott for sticking with my project even when it wasn't convenient, and Dr. Ana Luszczynska for stepping in at the last minute when I needed help. I would especially like to thank my major professor, Dr. Meri-Jane Rochelson, not only for her

excellent advice and guidance, but also for her tenacity in keeping my thesis project on track. Finally, I would like to thank God, with whom all things are possible. 
ABSTRACT OF THE THESIS

THE BROKEN MIRROR:

MATERNAL AGENCY AND IDENTITY

IN CHARLES DICKENS'S BLEAK HOUSE

by

Sarah Elizabeth Cash

Florida International University, 2013

Miami, Florida

Professor Meri-Jane Rochelson, Major Professor

This paper examined how Esther Summerson, Dickens's ideal good mother, can be understood as a woman who has maternal agency and identity both as a character and as a narrator, and how she contrasts with other maternal characters in the novel, both major and minor. While more transgressive mothers, such as Lady Dedlock, Mrs. Jellyby and even Krook's cat, are doomed to death, ineffectiveness and madness, Esther moves from a frozen, "unsexualized" state into a space of life and sexual possibility. In addition, Esther has agency and identity as a narrator since she shares the narration with a thirdperson male narrator. Esther becomes the one who speaks rather than the one who is spoken of, and her maternal, nurturing voice provides a balm for the often harsh, judgmental voice of the male narrator. As the narrator's patriarchal voice dies away at the end, it is Esther's maternal voice that survives. 


\section{TABLE OF CONTENTS}

CHAPTER

PAGE

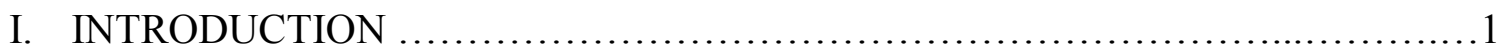

II. CHAPTER ONE

Houses in Bleak House: Uncanny Maternal Spaces ........................... 10

III. CHAPTER TWO

Black Ink and Black Fog: The Maternal Other ............................... 32

IV. CHAPTER THREE

The Ghost in the Mirror: Esther's Fragmented and Multiplied Identity

V. CONCLUSION

The Birds' Flight

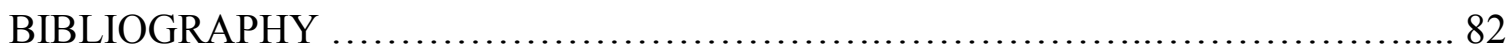




\section{INTRODUCTION}

When Charles Dickens wrote his novel Bleak House in 1852, it entered into a society filled with expectations and preconceptions of both women and motherhood. The Victorian society that surrounded the novel embraced a vision of an ideal woman as a type of angel in the house, or a virgin good mother, always nurturing and sacrificing for her children. Society's attitude is evident in an exhortation from a mother to her daughter before her marriage in 1804. In the anonymous article printed in "The Lady's Monthly Museum," the mother congratulates herself for preparing her daughter to be a treasure to her husband and exults "in the prospect of seeing her dear girl exchange her truly virgin charms for the 'virgin majesty' of the nuptial state" (97). The mother continues, citing Milton's conflation of virginity with Eve, “we see him [Milton] joining the youthful bloom, sweetness and innocence of the maid, with the sedateness and benign gravity of the matron" (97). The juxtaposition of the sweetness, innocence, and sacrificial pliability of the virgin with the role of the matron demonstrates not only a prevailing attitude in the $19^{\text {th }}$ century about a woman's role in the house, but also a hidden fear lurking behind this image of an unspoken patriarchal perception where a sexualized mother becomes dangerous and threatening. In Bleak House, Esther Summerson and her mother, Lady Dedlock, illustrate this duality. In the novel Esther, though she is still unmarried, is revealed as an epitome of the good Victorian mother because she is maternal without the power of her own sexuality, while her own mother, Lady Dedlock, becomes trapped and frozen in a death-like state because of her sexual sin, committed when she gave birth to Esther out of wedlock. 
Much of the scholarly criticism of Esther centers on Esther as the antithesis to feminist ideals of the rupture of gender roles in $19^{\text {th }}$ century literature and the power of women in society. According to many critics, since she becomes a woman who is forced by the constraints of her society to enact the role of the virgin good mother, Esther's agency and identity are thwarted as she moves through the role laid out for her by her male creator. Other critics assign Esther some semblance of agency, not in her own right as a character, but as an agent of revelation. These critics believe that Esther's agency can only be seen as the patriarchally enslaved voice that reveals the problem of silenced and constrained women. I argue, however, that Esther can be understood as a woman who has maternal agency and identity both as a character and as a narrator. As a character, Esther moves from her own frozen, "unsexualized" state into a space of life and possibility. Although Esther must move within the constraints of her society, she is still able to move and grow. Unlike her mother, who is destroyed in part by her own guilt and sexuality, Esther is somehow protected throughout the novel by her supposed maternal lack of sexuality, and in the end, through her own marriage, Esther is able to move away from her role as an ideal virgin mother and claim her own sexual power and possibility.

In addition, Esther has agency and identity as a narrator. The narration of Bleak House is split between Esther's first person narration and a third-person male narrator. Many critics argue that the male narrator is the more powerful narrator, and Esther's narration is, by contrast, weak and ineffective. I argue that Esther not only has agency because she has voice as a narrator, but that her narration takes power and authority away from the male narrator. Esther becomes the one who speaks rather than the one who is 
spoken of, and it is her narration and connection to the lives of others that propels the reader though the intricacies of Bleak House. In contrast, Lady Dedlock can be associated with the male, third-person narrator because her story is told through his seemingly omniscient and often judgmental voice. While Esther retains the power of her voice, Lady Dedlock, who becomes constrained and dominated by the patriarchal narrator, ultimately dies and is doomed to silence.

Charles Dickens's novel Bleak House begins with a description of London where ubiquitous smoke and fog reach in and around every part of the city, obscuring and veiling everything and every person until even the snowflakes go into mourning "for the death of the sun" (17). As the fog obscures the people and places of London, things cannot be seen clearly, and identities fade and become lost in the murky darkness. The London of Bleak House becomes an image of a dangerous and almost prehistoric space where "it would not be wonderful to meet a Megalosaurus, forty feet long or so, waddling like an elephantine lizard up Holborn Hill" (Dickens 17). It is in the murky, muddy and polluted city that Esther and Lady Dedlock, as maternal characters in Bleak House, lose their agency and identity as mothers and potential mothers. In the dark and poisonous world of London a woman's agency and sexual identity lead to death and tragedy. However, Esther, protected as an unsexualized mother survives the telling of her own story in the decayed world of Bleak House, and, by the nature of her survival, she is the only woman who regains the potential and possibility of her own agency.

The action in Bleak House begins with the two women around whom the entire novel will revolve, Lady Dedlock and her daughter, Esther Summerson. Lady Dedlock and her husband, Sir Leicester Dedlock, are aristocratic, wealthy leaders in both politics 
and society. The Dedlock name is an ancient name that is regarded throughout England with reverence and respect. In the beginning of the novel, the Dedlock's lawyer, Mr. Tulkinghorn, has visited Sir Leicester and Lady Dedlock in order to go over several affidavits for a lawsuit. The lawsuit, to which Lady Dedlock is only peripherally connected, is the court case Jarndyce and Jarndyce in which an inheritance has been disputed in Chancery ${ }^{1}$ for decades. When Lady Dedlock sees the handwriting on one of the documents, she starts and asks, "Who copied that?" (Dickens 29). Tulkinghorn cannot answer and begins to read again, but becomes concerned that Lady Dedlock is ill. "'Faint,' my Lady murmurs, with white lips, 'only that; but it is like the faintness of death"' (Dickens 29). Lady Dedlock's reaction sets up a series of events that will eventually connect and affect many characters in the novel, culminating in Lady Dedlock's death. The reason why Lady Dedlock reacts so strongly to the handwriting is that, many years before she was married, Lady Dedlock had an affair with a soldier, Captain Hawdon. As the result of their encounter, Lady Dedlock had a child. She believed that Captain Hawdon was killed and that their child died right after birth. However, in both instances, she was wrong. The child was taken by her sister, Miss Barbary, and raised in secret, and Captain Hawdon survived and made his living copying documents. Throughout the novel, Tulkinghorn, who knows from Lady Dedlock's reaction that there is a secret to uncover and wishes to have leverage over her, and Lady Dedlock struggle to reveal and conceal the secret shame that would destroy both Sir Leicester and the Dedlock name.

\footnotetext{
${ }^{1}$ English Civil Court
} 
Lady Dedlock's daughter, Esther Summerson, is raised by her strict and unloving aunt until Miss Barbary's death, when she is removed by a benefactor, John Jarndyce, to a school for girls. Esther spends many years at the school, both as student and teacher, until she is sent for and brought to the Chancery Court to be a chaperone for a young lady, Ada Clare. Ada Clare and her cousin Richard Carstone are both orphans who have a claim in the lawsuit, Jarndyce and Jarndyce. Their cousin, John Jarndyce, has petitioned the court to become their guardian, but he needs a chaperone for Ada, an office that Esther happily fulfills. Jarndyce takes Richard, Ada, and Esther to live with him in his house, and it is in Bleak House that Esther's role as a caretaker is fully realized. In response to Esther's tendency to sacrifice herself for others, her guardian chastises her, “'Tut! tut!' said he. 'But we must take care, too, that our little woman's life is not all consumed in care for others"” (Dickens 185). Esther replied, "'Care? My dear Guardian, I believe I am the happiest creature in the world!'” (Dickens 185). Esther's assertion that she is made perfectly happy as the self-sacrificial, nurturing caretaker of the house further solidifies, for the reader, not only the Victorian ideal of the woman's role in the house, but also the absolute joy that a good woman should feel when she fulfills that duty. Dickens, however, almost immediately problematises Esther's response when Esther, almost as an afterthought in her narration, adds, "I have omitted to mention in its place, that there was some one else at the family dinner party. It was not a lady. It was a gentleman. It was a gentleman of dark complexion - a young surgeon. He was rather reserved, but I thought him very sensible and agreeable. At least, Ada asked me if I did and I said yes" (Dickens 185). The young man to whom Esther refers is Alan Woodcourt, the doctor who she will eventually marry at the end of the novel. By placing 
Esther's first meeting with Woodcourt, as well as her first stirrings of desire both sexually and for something perhaps more than her ideal maternal role, next to her joyful acceptance of that role, Dickens seems to be hinting at a possibility, not only for Esther but for all women, of something more than the Victorian maternal ideal.

The other two young people who reside at Bleak House, Richard and Ada, become symbols of the youth and beauty that are condemned and wasted in the corrupt and ineffective Chancery Court. For Richard and Ada, it is the case Jarndyce and Jarndyce that dooms them to unhappiness. Because the case cannot be resolved, everyone involved in the Jarndyce and Jarndyce becomes trapped in a cycle of waiting and stagnation until legal costs devour the original inheritance, and, in Richard's case, his life, as he wastes away from illness caused by the stress of the lawsuit. The youth and beauty of Richard and Ada are contrasted with another ward of the court, Miss Flite. Miss Flite has been a ward of the court for so long that she has been driven mad and her life has withered away. Esther, Richard and Ada meet Miss Flite in Chancery, and she takes them to her room above Krook's shop. Krook is an odd old man who is known by his neighbors as The Lord Chancellor, and fills his shop with everything and anything he can because of his love for "rust and must and cobwebs. And all's fish that comes to my net. And I can't abear to part with anything I once lay hold of... or to alter anything, or to have any sweeping, nor scouring, nor cleaning, nor repairing going on about me. That's the way I've got the ill name of Chancery" (Dickens 65). It is later revealed that along with Miss Flite, Esther's father, Captain Hawdon, also lives above Krook's shop. Captain Hawdon, or Nemo as he is known, is said to have "sold himself to the devil" (Dickens 69), and is eventually found dead of an overdose of opium. 
Before they reach Bleak House, Esther, Ada, and Richard also encounter Mrs. Jellyby, a comic character and mother of a large number of children including little Peepy, Mrs. Jellyby's young neglected son, and Caddy, Mrs. Jellyby's eldest daughter. Instead of caring for her home or children, Mrs. Jellyby spends her time dictating letters to her daughter Caddy on her favorite philanthropic cause, Africa. Esther's maternal importance becomes apparent in the Jellyby house as she extends her mothering nurture to the Jellyby children, especially little Peepy. Ada says of Esther, "'You are so thoughtful, Esther... and yet so cheerful! And you do so much, so unpretendingly! You would make a home out of even this house"” (Dickens 55).

In the first chapter, as I introduce my thesis about maternal agency in Bleak House, I look at the maternal as a potentially uncanny space. Through the connection of the uncanny with the home, I argue that Bleak House, Chesney Wold, the Jellyby house, and Krook's shop all become, in different respects, both maternal and uncanny, and, with the exception of Bleak House which can be viewed as more protective than threatening, the mothers and maternal figures in these spaces become trangressive and dangerous. As transgressive mothers, these maternal figures expose how the mother who threatens must become the mother who is silenced in the patriarchal construction. On the other hand, Dickens also reveals that many of the corrupt patriarchal constructions, including Chancery, must also be combusted and destroyed. Esther stands out in this chapter as a maternal figure who survives because she is not threatening, and also because her qualities as a good mother help and succor those around her.

In the second chapter, I focus on the duality of Esther and Lady Dedlock, their connection as mother and daughter, and the black ink and London fog that become 
symbolic of the corruption of Chancery and the patriarchal oppression that forces Lady Dedlock into a stagnant, sterile existence. Esther, as the opposite image of her mother, becomes the epitome of a type of virginal, good maternal caretaker who, despite her forced role in a patriarchal construction of a woman's identity, is able to combat the black ink and fog through her own narration and maternal voice. Also, it is Esther's maternal narrative voice that continues when the male narrator's patriarchal voice is silent.

In the third chapter, I examine Esther as a simultaneously canny and uncanny character. Although she combats some of the negativity of uncanny spaces and bad mothers, she is also revealed as a ghostly presence in the novel. Esther's connection to Lady Dedlock becomes like a broken mirror, and while they are separated, her identity is fragmented and trapped in the construction of the unsexualized mother. As Esther connects with and then releases her mother, she begins to move away from her identity as the unsexualized other. When Lady Dedlock dies, Esther is able to figuratively unbury herself and partially embrace her own sexuality and identity. However, although Esther is in one sense free from her ghostly existence, she still retains traces of her multiplied and broken identities, and at the end, Esther remains a fragmented character. Still, it is in the spaces between the multiple facets of her identity that Esther has agency and possibility both in her marriage to Woodcourt and in her continued voice.

In Bleak House, Charles Dickens works both in and against the Victorian constructions of the maternal ideal. On one hand, Dickens presents his character, Esther Summerson, as the epitome of the Victorian good mother, and it is only through her adherence to this ideal that Esther is able to nurture the other characters and ultimately survive to fulfill her potential. Dickens condemns those maternal characters who dare to 
resist the patriarchal constructions that surround them to ridicule, madness and death.

On the other hand, Dickens also condemns certain patriarchal constructions, most notably Chancery and the ancient Dedlock lineage, to impotent stagnation and symbolic destruction. Most significantly though, Dickens also allows Esther her own narration. In Bleak House, it is Esther's ability to nurture, survive and speak that demonstrates the true power of the maternal to evoke generation, possibility, and change. 


\section{CHAPTER ONE}

\section{Houses in Bleak House: Uncanny Maternal Spaces}

In the midst of muddy, black, and foggy London stands the space from which the novel gets its name - Bleak House. Originally, Bleak House was a part of the dark and ruined landscape of London, and its late owner, Tom Jarndyce, destroyed over his obsession with the court case, Jarndyce and Jarndyce, lived in the house alone until he finally shot himself. John Jarndyce describes Tom Jarndyce as a man who shut himself up, "day and night poring over the wicked heaps of papers in the suit [Jarndyce and Jarndyce]...In the meantime, the place [Bleak House] became dilapidated, the wind whistled through the cracked walls, the rain fell through the broken roof, the weeds choked the passage to the rotting door. When I brought what remained of him home here, the brains seemed to me to have been blown out of the house too; it was so shattered and ruined" (105-106). When John Jarndyce moves into Bleak House, he transforms the house into a new and hopeful place. John Jarndyce holds himself apart from the Court of Chancery and the law suit Jarndyce and Jarndyce, and in this way, he is able to at least partially protect himself from the evil effects of Chancery. John Jarndyce creates, in Bleak House, a kind of protected womb where he tries to bring those he loves to keep them safe. The womb or space that Jarndyce creates is, however, still exposed to the effects of the rotten and diseased world outside, an exposure represented by the wind that beats against the house and blows "easterly" whenever something is not quite right with the world. In his article "The Urban Gothic of Bleak House," Allan Pritchard argues that "the winds to which Bleak House is exposed are...symbolic winds of moral and social failure, emanating from such institutions as the Court of Chancery, and winds of 
disease and pollution from the great city" (436). The exposure of Bleak House explains why, for example, Richard Carstone, who Jarndyce brought into the protected space he created, cannot be saved from death. Neither the protected womb of Bleak House nor Esther, the good mother of the house, can save Richard from the evil poison of Chancery. Looking at the home as a created maternal space brings the home itself into a kind of doubleness. Bleak House exemplifies this double nature of the home because it is paradoxically both a shelter and private space of refuge, and a space that has been invaded and transformed by the public sphere. Because Bleak House can be seen as a refuge that is at the same time made bleak by the infiltration of the court case that "blew the brains out" of the home, it is transformed into something uncanny. Viewing the home as an uncanny space, Jeannie Suk looks at the law and the home and "reflects on the meanings of the home as simultaneously the source of security against and the focal point of anxieties about crossing between the categories of the private and the public" (291). The court case Jarndyce and Jarndyce causes Bleak House to become this simultaneous source of both security and anxiety. John Jarndyce himself comes into possession of Bleak House because Tom Jarndyce shot himself over his anxiety over the court case, and all of the other occupants, Richard, Ada and Esther, enter and reside in the home because they have been displaced by the same case. What should have been private and safe has been made public and dangerous by the dark shadow of the Court of Chancery. In this way, Bleak House becomes paradoxically both safe and dangerous as it is simultaneously a sheltering haven and a space corrupted by the intrusion of the shadow of the public sphere. 
The idea of the uncanny as belonging to the home was explored by Sigmund Freud in his essay on the uncanny. Freud notes that "the uncanny is that class of the frightening which leads back to what is known of old and long familiar" (825). By examining the etymology of the German word unheimlich, Freud attempts to understand how something could be simultaneously frightening and familiar. According to Freud, unheimlich is the opposite of heimlich which can be defined as "belonging to the house, not strange, familiar, tame, intimate, friendly, etc.” (826). On the other hand, Freud notes that heimlich also has a second meaning: "Concealed, kept from sight, so that others do not get to know of or about it, withheld from others" (827). Because of this double meaning, the word heimlich exhibits a meaning that is the same as its opposite, unheimlich. "Thus," according to Freud, "heimlich is a word the meaning of which develops in the direction of ambivalence, until it finally coincides with its opposite, unheimlich" (828). Using this definition of the uncanny, Bleak House becomes a kind of haunted house, an uncanny house that becomes the familiar, the homey and the intimate and at the same time, the secret, the mysterious, and the dreaded. In the preface to Bleak House, Dickens wrote, "In Bleak House, I have purposely dwelt on the romantic side of familiar things" (6). ${ }^{2}$ Christopher Herbert argues that Dickens's preoccupation with the romantic side of familiar things causes the entire novel to become an exercise in the uncanny. He notes that, from the beginning, even the doubled narrator enters into this idea of the uncanny. The third person narrator "represents among other things the pole of 'romantic' vision. From his perspective reality everywhere becomes impregnated with

\footnotetext{
${ }^{2}$ The editor, Tatiana M. Holway, notes that the idea of the romantic side of familiar things was put forth by Dickens in Household Words, March 30 1850, when he said, "To show to all, that in all familiar things, even in those which are repellant on the surface, there is Romance enough, if we will find it out" (825).
} 
the fantastic and seems, indeed, perpetually on the verge of dissolving into phantasmagoria" (102). In Herbert's view, the third-person narrator becomes like the megalosaurus, a voice of the romantic and fantastic and often horrifying. In contrast, Esther becomes the familiar as she represents the reality of the domestic routine and the private life of the family as they move through their mundane lives. As a representation of an uncanny space, Bleak House is associated with the romantic and fantastic public world of Jarndyce and Jarndyce, the megalosaurus of chancery and the male narrator, while at the same time it is filled with the domestic private world of Esther.

As mentioned before, the uncanny can be associated specifically with the home, but it is also interesting to note that the uncanny can also be associated with birth. Maria Tatar argues that the uncanny can be particularly associated with birth in Dickens's novels. 'Dickens' novels rarely plunge the reader in medias res. They generally begin $a b$ ovo, with the 'canny moment,' to speak the language of the Scots" (178). ${ }^{3}$ Tatar points to Dickens' novel David Copperfield in which the story begins with Copperfield's birth and continues with Copperfield's remembrance. "This remembrance of things past - of the distinct impressions registered on the child's mind as it grows to adolescence and maturity - holds the key to uncanny moments of recognition in Dickens' novels" (178179). Though Bleak House does not exactly begin with Esther's birth, it does begin with Esther's remembrance: "I can remember, when I was a very little girl indeed, I used to say to my doll, when we were alone together..." (Dickens 30). Esther remembers as far back as she can, but she cannot remember her own birth. Her aunt will never talk to her

\footnotetext{
${ }^{3}$ Tatar notes that according to the Scottish National Dictionary, "the 'canny moment' signifies the moment of childbirth" (178).
} 
of her mother or her birth, so Esther's own "canny moment" becomes uncanny, secret and hidden from her. As Esther enters into Bleak House, she begins to experience a kind of re-birth or a new beginning. Bleak House becomes a protected space that nurtures Esther in the way that her mother could not and her aunt refused. Bleak House is both a protective mother and a protective womb.

However, as a womb or maternal space, Bleak House continues to exhibit its double nature as a space that is both familiar and threatening. As Freud examines the different experiences that are considered uncanny, he notes that to some people, one of the most uncanny experiences of all is the idea of being buried alive: "To some people the idea of being buried alive by mistake is the most uncanny thing of all. And yet psycho-analysis has taught us that this terrifying phantasy is only a transformation of another phantasy which had originally nothing terrifying about it at all, but was qualified by a certain lasciviousness - the phantasy, I mean, of intra-uterine existence" (835). As a type of protected womb, Bleak House illustrates this idea of the uncanny intra-uterine existence. Before John Jarndyce transformed Bleak House into a protective space, Tom Jarndyce was symbolically buried alive within the rotting doors and walls of the house. After his death, he was brought back to the house, and his remains were figuratively entombed within the walls, at least in the days before his burial. In this way, Bleak House is associated with the uncanny experience of being buried alive. At the same time, when Jarndyce attempt to make Bleak House familiar and homey, he reveals that Bleak House can also be seen as a type of intra-uterine experience. The irony of Bleak House as a womb space, however, is that Bleak House is also an unsexualized space. John Jarndyce is an unmarried man and thus his home, however cocoon or womb-like, is not 
sexual. When Esther enters the house and takes on the role of housekeeper, she solidifies the house's unsexual role. Although John Jarndyce proposes to Esther, she looks on him as a father, so the proposal itself and her eventual, reluctant acceptance of it, does not change the role of Bleak House as an unsexual, maternal space. By placing Esther as an unsexual nurturing mother in Bleak House, an unsexual protected space, Dickens creates a space that contrasts sharply with the London outside of Bleak House and Chancery itself. As an unsexualized space positioned inside the dangerous, contaminated world that surrounds it, Bleak House is able, like Esther, to protect and nurture its inhabitants, and it is in this space that Esther is able to survive. However, this space is also the space created by Tom Jarndyce and Jarndyce and Jarndyce, and because it is a threatening, uncanny space, Richard and Ada cannot be protected and ultimately, Richard dies. Thus Bleak House has an ambivalent role in the novel because it is both a protective womb and an uncanny space created by its association with Chancery. At the end of the novel, when Esther marries and leaves Bleak House, she leaves the Bleak House that has been corrupted by the public sphere to create her own Bleak House apart from the influence of Chancery.

If Bleak House is a space that tries to protect, The Dedlocks' place in Lincolnshire, Chesney Wold, becomes a space that symbolically buries its inhabitants alive within its walls. Chesney Wold is described as a place of stagnation: "An arch of the bridge in the park has been sapped and sopped away. The adjacent low-lying ground, for half a mile in breadth, is a stagnant river, with melancholy trees for islands in it, and a surface punctured all over, all day long, with falling rain” (Dickens 24). Chesney Wold is also associated with death and there "is a general smell and taste as of the ancient 
Dedlocks in their graves" (Dickens 24). If both houses are then uncanny spaces, Chesney Wold, unlike Bleak House, becomes a space or a womb that is not protected or protective. Chesney Wold becomes rank and dangerous because it hides a sexual secret. Though Chesney Wold is frozen and stagnant, the eventual fall of the house, Sir Leicester, and the Dedlock line can be traced back to Lady Dedlock's sexual transgression with Captian Hawdon and the subsequent birth of their daughter. In this way the fall of the house of Dedlock is a sexual fall that begins with the sexual "stain" of a woman, and Chesney Wold becomes simultaneously a space of stagnation and death and a space of the consequences dangerous sexuality.

The duality of Bleak House, the unsexual womb, and Chesney Wold, the dangerous tomb, highlights the problematic dichotomy of the mother in Bleak House. On one hand, Esther, as the virtuous good mother, is celebrated in the novel for her kindness and ability to nurture and protect those around her. On the other hand, like Bleak House, Esther ultimately cannot save or protect Richard and Ada from the threatening outside world. Also, Esther seems almost trapped in a patriarchal construction of Bleak House that forces her to mold herself into a virgin, good mother. Chesney Wold, the more threatening and transgressive space, is doomed, along with Lady Dedlock, to stagnation and death. It seems that the sexual mother who threatens to become powerful by transgressing the boundaries inscribed by society cannot be allowed to flourish or survive. Reviewing, Uncanny American Fiction: Medusa's Face, Allan Gardner LloydSmith's study of the Medusa in Helene Cixous's essay “The Laugh of the Medusa," John Zhang notes that what is missing in Freud is "the relation of the woman to the castration complex: she is already 'on the other side,' not fearing that fate, but implicitly threatening 
it" (4). Zhang continues, "Here Lloyd-Smith, taking advantage of Lacan's poststructuralist insights, is arguing that the woman, always considered as the Other; excluded from the male-dominated discourse, already exists on the other side of the signifier" (124). The threatening woman becomes an uncanny symbol when she becomes an intimidating force in fiction. The woman as a Medusa figure threatens the male with "petrification" if he dares to look at her, but if he did dare to look, he would see, as Cixous posits, that she is laughing. Zhang argues that "According to Lloyd-Smith, the woman as the agent of the uncanny fights in this world either by smashing the male dominance or by giving the male rebirth. The uncanniness results partly from the disparity between the woman's inner self and the outer social and cultural codes regarding how women should behave" (125).

As a woman, Esther is the already castrated, the already othered. She already exists on the other side of the patriarchal discourse in Bleak House. At the same time, however, she is unable or unwilling to enter into a fully uncanny role. She continues to live protected or trapped in Bleak House, and she continues to fulfill her role as the Virgin housekeeper and Angel of the House. Esther is a woman who obeys the cultural and social codes of her time, and in many ways, she is completely unthreatening to the male discourse that surrounds her. However, though Esther does not fulfill the role of the Medusa as a threatening or petrifying force, she does begin to obtain the agency of the type of powerful woman the Medusa figure signifies. In many ways, Esther becomes a more benign Medusa, undermining patriarchal society while simultaneously adhering to patriarchal conventions. Unlike the Medusas who petrify but are doomed to stagnation and death like Lady Dedlock, Esther is able to survive and eventually flourish. 
In direct contrast to Esther, the good mother of Bleak House in Dickens's view, another mother, Mrs. Jellyby, stands out as a bad mother. Mrs. Jellyby is particularly interesting because in many ways, as an antithesis to Esther, she becomes an uncanny Medusa, smashing and threatening male domination in the novel. On their way to Bleak House, Esther, Richard and Ada stay at the home of Mrs. Jellyby who is described as "a lady of very remarkable strength of character who devotes herself entirely to the public. She has devoted herself to an extensive variety of public subjects, at various times, and is at present (until something else attracts her) devoted to the subject of Africa" (Dickens 48). Mrs. Jellyby devotes herself to the public, but the private sphere of her life is totally neglected. Mrs. Jellyby becomes a Medusa who petrifies her husband into a nonentity. “And of Mr. Jellyby, sir?”suggested Richard. "Ah! Mr. Jellyby," said Mr. Kenge, "is -a-I don't know that I can describe him to you better than by saying that he is the husband of Mrs. Jellyby."

“"A nonentity, sir?” said Richard, with a droll look.

"I don't say that," returned Mr. Kenge, gravely. "I can’t say that, indeed, for I know nothing whatever of Mr. Jellyby" (Dickens 48).

As a powerful and strong woman, Mrs. Jellyby completely overshadows her husband to the point that he cannot even be described. He is nothing more than the husband of Mrs. Jellyby and an entity who cannot even be known as a nonentity because he is completely unknown by the other characters in the novel. Mrs. Jellyby not only overshadows her husband, she completely neglects her children and her house. Where Esther is the epitome of the Victorian good mother, the Angel of the House, Mrs. Jellyby is the bad mother, and her house and family are always in complete disorder and chaos. Before 
they even enter the house, Ada, Richard and Esther are confronted with one of Mrs. Jellyby's children stuck in the railing. "I made my way to the poor child, who was one of the dirtiest little unfortunates I ever saw, and found him hot and frightened, and crying loudly, fixed by the neck between two iron railings" (Dickens 49). Little Peepy, as the child is called, is rescued and brought inside, but his mother refuses to comfort him. Instead, it is Esther who must take the little boy up and nurse and nurture him. The only one of Mrs. Jellyby's family who does not seen to be ignored is her daughter Caddy. As was mentioned before, Caddy is forced to take dictation from her mother concerning Mrs. Jellyby's African projects, a circumstance that Caddy bitterly resents. Caddy says to Esther, "The whole house is disgraceful. The children are disgraceful. I'm disgraceful. Pa's miserable, and no wonder...I wish I was dead!...I wish we were all dead. It would be a great deal better for us" (Dickens 58-59). Caddy's concerns are clear, Mrs. Jellyby has broken from the male dominant tradition of the perfect housekeeper and mother, but her own children must pay a price.

Joan Manheimer argues that despite Dickens' intention to portray Mrs. Jellyby as a terrible mother, her character suggests "a feminist alternative to the sacrifices demanded by the feminine ideal" (536). According to Manheimer, though Mrs. Jellyby is a bad mother, she exerts a measure of power and agency as a woman because of her refusal to bend to the ideal of maternal sacrifice. Manheimer also notes that Dickens seems “curiously lenient toward Mrs. Jellyby. Mrs. Jellyby's household may be dirty, but no one sickens from the grime. Her children may fall every which way, but Dickens's perspective makes them art works rather than sufferers" (538). In addition, Manheimer argues that the two Jellyby children whose suffering is most visible, Caddy 
and Peepy, turn out well (538). Manheimer is correct that the Jellyby children seem relatively healthy and that Caddy and Peepy are able to overcome in some respect their mother's neglect, but I also argue that they are only able to do so in spite of their mother. In order to succeed in life, Caddy and Peepy have to separate themselves from Mrs. Jellyby, Caddy through marriage and Peepy through his ability to leave and find work with a patron. Also, like her male counterpart Harold Skimpole, a childlike father who neglects his own children, Mrs. Jellyby is a comic character and her treatment of her home and children is meant to simultaneously horrify and amuse. It must be noted however, that Mrs. Jellyby's children have a home and food. Though they are in many ways like orphans, they are not completely neglected because they still have a father who provides income, a sister who tries to care for them, and even Esther, who has a maternal impact in their lives. Dickens makes a clear distinction in the novel between a bad mother or caretaker and no mother. Though Mrs. Jellyby's neglected children are like orphans, they, like Esther, are still cared for and suffer less than Jo, the orphan boy who lives and suffers on the streets on London and ultimately dies in the novel. However, in Bleak House Mrs. Jellyby's children do suffer. They are not merely works of art sketched for admiration or amusement, and Mrs. Jellyby's refusal to sacrifice for her family results in real consequences for her children.

The suffering of children is one of Dickens' concerns in Bleak House. Esther's recollections of her own childhood reveal her own emotional and psychological suffering at the hands of her aunt. We are also introduced to the suffering of Harold Skimpole's children; Mrs. Jellyby's children including Caddy and Peepy; Charley, Tom and Emma who are orphaned when their father dies; and the sufferings of the orphan, Jo. 
Manheimer suggests that since Caddy and Peepy Jellyby turn out relatively well in the novel, the reader can infer that Mrs. Jellyby is somehow somewhat effective as a mother, and "the Terrible Mother is of more use to her child than we are invited to suppose and a more complex figure than the standard moral response will admit” (538). As a good mother, Esther, according to Manheimer, becomes ineffective and helpless because she cannot "salve the injustices of the world" (538). In support of her theory, Manheimer cites Esther's failure to save Richard, Jo and Lady Dedlock from the social system. Manheimer's argument, however, breaks down when one considers that it is Esther who helps and "mothers" Caddy and Peepy, perhaps providing the needed support for their success. Young Charley becomes Esther's maid, and through John Jarndyce, who perhaps as a selfless caretaker can be viewed as Esther's male counterpart in the novel, Charley and her brother and sister are saved from a life of abject poverty and perhaps starvation. Although it is true that Esther cannot save all those who suffer at the hands of a corrupt system, she does give Jo comfort and care during his illness, and, though she cannot save Richard from Chancery, she does care for Ada who endures to bear her husband Richard's son. It is interesting to note that although Richard and Ada's son can be seen as a continuation of generation, Ada herself ends up taking Esther's place in Bleak House after Richard's death. It is almost as though Ada becomes trapped in the space that Esther escapes, and although Ada does not marry John Jarndyce, she and her son are dependent on him because of Ada's limited ability to sustain herself as a woman in a patriarchal Victorian society. Ada and Richard's son, however, does survive and it is Esther who is able, through her maternal sacrifice, to ease the suffering of those around her. 
In addition to their roles as bad and good mothers, Mrs. Jellyby and Esther are counterparts in the novel in terms of their sexuality. While Esther is an unsexual mother, Mrs. Jellyby becomes a sexual mother who refuses to nurture her children. It is interesting to note that Mrs. Jellyby is perhaps the most overtly sexual of all of the mothers in Bleak House. As the mother of a large number of children, Mrs. Jellyby is automatically associated with fertility and sexuality. In addition, as Dona Budd notes, Mrs. Jellyby's physical description is both open and sexual. According to Budd, Mrs. Jellyby's clothes and body suggest the connection between unleashed female language and female sexual power. Esther describes Mrs. Jellyby as a plump, pretty woman with "very good hair, but (she) was too much occupied with her African duties to brush it. The shawl in which she had been loosely muffled, dropped on to her chair when she advanced to us; and as she turned to resume her seat, we could not help noticing that her dress didn't nearly meet up the back, and that the open space was railed across with a lattice-work of stay-lace - like a summerhouse" (Budd 204-205).

In addition to Mrs. Jellyby's ability to procreate and her sexually described dress and body, Mrs. Jellyby's association with Africa also connects her intimately with sexuality. Since colonial exploration of Africa became more prominent in the mid $19^{\text {th }}$ century, the perception of the continent of Africa as a mysterious and hidden place may have been on Dickens's mind when he chose Africa as the site of Mrs. Jellyby's charitable attention. ${ }^{4}$

\footnotetext{
${ }^{4}$ Patrick Brantlinger notes that, "The Scramble for Africa may have occurred largely in the last two decades of the nineteenth century, but the intense public interest in the 'penetration' and 'opening up' of the supposedly Dark Continent began seven or eight decades earlier with the abolitionist movement and culminated in Thomas Fowell Buxton's ill-fated Niger Expedition of 1841" (28).
} 
In addition, Dickens may also have been thinking of ideas surrounding Africa and sexuality similar to Freud's later connection of the African Continent ${ }^{5}$ with a woman's sexuality. Cixous criticizes Freud's association of women with the dark and mysterious. "The Dark Continent is neither dark nor unexplorable. - It is still unexplored only because we've been made to believe that it was too dark to be explorable. And because they want to make us believe that what interests us is the white continent, with its monuments to Lack" (1951). Dickens may perhaps be one of Cixous's "they" who look at the sexuality of a Mrs. Jellyby as something dark and lacking. ${ }^{6}$ Mrs. Jellyby's sexuality is connected to her role as a bad mother while Esther's lack of sexuality can be associated with her role as a good mother.

In addition, Mrs. Jellyby's association with Africa could expose a possible inclination in Dickens to look at the "black" races as somehow defiling. Patrick Brantlinger argues, "Europeans found their savage impulses were never far from their civilized surfaces; the potential for being 'defiled,' for going native, led them again and again to displace these impulses onto Africans...so the myth of the Dark Continent contains the submerged fear of falling out of the light into the abyss of social and moral regression" (194). Mrs. Jellyby's unkempt, wild, sexual appearance; her disordered house; and her uncared for, almost untamed children reveal that her obsession with Africa has somehow caused her own social and moral responsibilities to regress. Mrs. Jellyby's

\footnotetext{
${ }^{5}$ See Frued's "Femininity"

${ }^{6}$ Although written later than the publication of Bleak House, it is interesting to note the connection of Africa as a dark continent in the Victorian Imagination. Lucy Jarosz notes: "The earliest written reference to Africa...as the Dark Continent was penned by Henry M. Stanley...At the end of his journey on the Zambezi River in the latter half of the nineteenth century, Stanley wrote: '...I felt my heart suffused with purest gratitude to Him whose hand had protected us, and who had enabled us to pierce the Dark Continent...'(1878; p.467)" (106).
} 
apartment regression could also be connected to the general decay of society that Dickens perceives in London itself. However, for Dickens, the decay seems to reflect back on Londoners like Mrs. Jellyby who want to believe that their goodness and morality must tame and "help" the "savage" races without looking to their own immorality in the defiling of their own homes.

Dickens's portrayal of Mrs. Jellyby's African philanthropy highlights what Patrick Brantlinger calls Dickens's "hostility toward evangelical philanthropy" and he quotes Dickens saying, "The work at home must be completed thoroughly, or there is no hope abroad" (178). Dickens's attitude demonstrates that Mrs. Jellyby's lack as a mother is connected to her willingness to sacrifice her children to the perceived superiority of her cause. Through Mrs. Jellyby, Dickens critiques the tendency of empire to neglect the children at home in favor of children abroad.

However, despite Dickens's critique of Mrs. Jellyby's “Telescopic Philanthropy” (Dickens 48), Mrs. Jellyby, as a sexual, uncanny character, in some ways achieves what Esther cannot; she subverts male authority and threatens patriarchal constructions. Dona Budd argues that in Bleak House linguistic power is often associated with destructiveness and self-indulgence (204). Budd looks to a scene near the middle of the novel to illustrate this connection. The scene consists of an observation by Esther of a young country bride who marries a young illiterate man and though the young woman can write, to avoid shaming her new husband, she marks an " $x$ " on the marriage certificate instead of signing her name. Budd notes that "She also fulfills an idea of Victorian womanhood - gentle-hearted, delicate, considerate, self-sacrificial, and Christian - in trading her literacy for a rude cross" (198). In this way, the bride is herself like Esther, the ideal 
woman, and she is exactly the opposite of Mrs. Jellyby who, instead of sacrificing her literary power for her family, sacrifices her family for her literary power. According to this argument, as a selfish and destructive character, Mrs. Jellyby should exert linguistic power in the novel, and Esther should be forced to trade her literacy for her selfsacrificial ideas. Ironically, however, the opposite seems to be the case. Though Mrs. Jellyby is associated with literacy because of the massive amounts of correspondence she composes for Africa, she does not really achieve anything through her writing. Instead, she spends her literacy dictating reams of worthless letters that are not unlike the reams of worthless documents that pile up in the case of Jarndyce and Jarndyce. Literacy and words themselves become destructive when they are misused, and Mrs. Jellyby, though she is an uncanny mother, is ultimately silenced in the text. Unlike Mrs. Jellyby who engages in worthless words, Esther, as a narrator, is able to overcome the silence of the country bride and become the speaking good mother.

It is also interesting to note here that Mrs. Jellyby dictates her correspondence to her daughter Caddy, and Caddy becomes an ink covered drudge who has no linguistic power at all because she can only repeat her mother's words. It is only when Caddy breaks free from the bad mother that she can begin to find her own voice and her own sexuality through her marriage. In Bleak House, Mrs. Jellyby, though she threatens male dominance, is ultimately ineffective as an uncanny mother. Her voice does not have power in the novel, and, in the end, she takes away the voice of her own daughter when she sacrifices Caddy's individual voice to her own ambition. In contrast, Esther is able to preserve the power of her voice while also retaining her self-sacrificial, nurturing ideals. 
As the reigning "Medusa" of her house, Mrs. Jellyby becomes the uncanny mother of the Jellyby house as Esther is the mother of Bleak House and Lady Dedlock is the mother of Chesney Wold. Of all the uncanny spaces in Bleak House, including the nurturing yet unsexaulized space of Bleak House, the sterile yet sexualized space of Chesney Wold and the sexualized yet un-nurturing space of the Jellyby House, perhaps the most uncanny space of all is Chancery itself. If the Lord Chancellor can be compared to a kind of dark mother, then Chancery itself becomes the poisonous womb or uncanny space that surrounds him. Dickens presents his reader with Krook's shop and boarding house as an allegory for Chancery, and to make sure that there is no confusion as to what Krook and his shop represent, Esther, Ada and Richard, who enter the shop with the little old lady Miss Flite, are informed that "He is called among the neighbors the Lord Chancellor. His shop is called the Court of Chancery" (Dickens 64). Krook, a man described as "short, cadaverous, and withered" (Dickens 64), confirms Miss Flite's description and adds that he obtained the ill name of Chancery because he cannot bear to part with anything and his neighbors think that his shop is filled with things "wasting away and going to rack and ruin" (65). In many ways, Krook's shop is an unsexualized space like others we have seen. Krook himself has no wife or children and his two lodgers are both decayed and sterile characters. Miss Flite is not only an unmarried old woman, but she is also a ward of Chancery and spent her entire life wasting away, locked up in Krook's shop like his withered things, waiting for judgment. Krook's other lodger is Nemo, the law writer and Esther's father. Nemo, though he has a daughter and was previously highly sexual, has no knowledge of her, and so becomes symbolically unsexualized as he withers and rots away, an empty character that simply waits for death. 
In many ways Nemo and Miss Flite are both like the living dead, and so Krook's shop becomes a haunted house and a house of death. The association of Krook's house with death is furthered when Nemo is discovered dead in his room, and when Krook himself dies in his own shop.

But, though Krook's shop can be associated with sterility and death, it is also simultaneously a sexual space. The sexual nature of Krook's shop is best represented by his cat, Lady Jane. According to Tatiana Holway in her notes on Bleak House, Krook's cat is named for Lady Jane Grey who was the Queen of England for nine days in 1553. After Lady Jane Grey was forced to abdicate her throne, she was placed in prison and later beheaded (830). The association of Krook's cat with a dead queen allies Lady Jane to both royalty and death. Robert Lougy argues that Lady Jane can also be seen as a feminine presence in the novel (486). According to Lougy, however, Lady Jane is not just any feminine presence, she is a transgressive presence that is "deeply and enigmatically inscribed within the dynamics of abjection and desire" (486). In support of his theory, Lougy looks to a possible interpretation of Lady Jane's name as coming from $19^{\text {th }}$ century slang for a woman's genitals. ${ }^{7}$ If Lady Jane can be seen as some sort of threatening female sexual presence, than perhaps Lady Jane becomes the epitome of the dark mother as she represents feminine sexuality at its most dangerous and animalistic. Speaking again of Lady Jane as a symbol of female genitalia, Lougy also notes the significance attached to hair. As an animal, Lady Jane is a creature covered in hair.

\footnotetext{
${ }^{7}$ Lougy references a passage from Eric Partridge's A Dictionary of Slang and Unconventional English, “'Lady Jane' was, ca. 1850, a vulgar slang expression for the female genitals" (487). Lougy adds that "given Dickens's familiarity with the language of the street, it is likely that he would have known of its meaning" (487). In addition, Lougy notes that "Georgy Lear, a friend of Dickens, writes, for example of how, 'I thought I knew something of the town, but after a little talk with Dickens I found that I knew nothing'” (487).
} 
Also, Krook himself fetishises women's hair through both his collection of hair and his obsession with and fondling of Ada's hair (Lougy 487-488). Lady Jane then, the hairy sexual organ with claws and sharp teeth, represents female sexuality as a cruel, beastly, devouring mouth. Lougy continues, "Characterizing the image of the feminine as mouth or hole, Sartre observes that 'the obscenity of the feminine sex,' is that 'of everything that gapes open...her sex is a mouth and a voracious mouth which devours the penis"” (488). Lady Jane represents female sexuality at its most transgressive and threatening to patriarchal fears, particularly the fear of castration.

The threatening sexuality of Lady Jane is also connected to death, particularly the death of Krook. Krook's death occurs in the middle of the novel in a chapter titled "The Appointed Time," as though God himself, or perhaps the god-like narrator, had ordained the specific time and means of Krook's demise. Before the reader knows that Krook has died, the narrator prepares the scene by describing a dark, cold night as Mr. Weevle, the tenant who moved into Nemo's room, returns to his lodgings while talking with an acquaintance, Mr. Snagsby. Both men notice something different in the air, a queer flavor or smell that they cannot quite place. Soon after, Mr. Weevle meets up with his friend Mr. Guppy and they enter his room. Both men notice a strange substance, like soot, falling on the furniture and adhering to their clothes. As Mr. Guppy sits on the window-sill, he gets some of the strange substance on his hands:

'What, in the Devil's name,' he says, 'is this! Look at my fingers!' A thick, yellow liquor defiles them, which is offensive to the touch and sight and more offensive to the smell. A stagnant, sickening oil, with some natural 
repulsion in it that makes them both shudder...it slowly drips, and creeps away down the bricks; here, lies in a little thick nauseous pool (Dickens 433).

As the two men venture downstairs, they discover what remains of Krook, a small pile of ash, and the narrator explains:

The Lord Chancellor of that Court, true to his title in his last act, has died the death of all Lord Chancellors in all Courts...it is the same death eternally inborn, inbred, engendered in the corrupted humours of the vicious body itself, and that only - Spontaneous Combustion, and none other of all the deaths that can be died (436).

The substance that covered the house and the furniture, dripping down the walls onto Mr. Guppy and Mr. Weevle, that thick, yellow smelly grease turns out to be the body of Krook himself, combusted from within and burnt to a pile of ash. Lougy makes a sexual connection to Krook's combustion and dispersal through Sartre's meditations on slime and the feminine: "He [Sartre] describes the particular fusion that takes place when honey slides from the spoon into the honey jar, for example, as a 'spreading out - like the flattening of the full breasts of a woman who is lying on her back.' and speaks of the 'soft, yielding action, a moist and feminine sucking' of slime and its 'sickly-sweet, feminine revenge"' (486). Although Krook's remains can hardly be described as sweet, the idea of a sliding, sickly substance does seem to connect to the horrifying idea of Krook's body oozing down one's skin and being breathed into one's body. The connection of feminine sexuality to Krook's death, the horrifying nature of that death, and the connection of Lady Jane to threatening female genitals makes Krook's shop a maternal space of fear and horror, an uncanny home where the men are spewed from its 
womb either in death like Nemo and Krook, or abject terror like Mr. Guppy and Mr. Weevle who flee from the spectacle of Krook's remains.

As Weevle and Guppy flee Krook's shop, the only character that remains, staring at the "body" is Lady Jane, apparently driven mad by her master's horrible death. Krook's connection to Chancery and the Lord Chancellor, the inborn, corrupted presence that dies eternally by spontaneous combustion, makes Lady Jane's final presence particularly interesting because she is the transgressive female presence who has survived the combustion. In some ways, Chancery is a part of a decayed patriarchy with its connection to Sir Leicester and ineffective, dangerous, and out-dated traditions. Krook also becomes a type of corrupted, patriarchal figure that must ultimately be burned up from within. Simultaneously, however, both Krook and Chancery are connected to a dark, female sexuality that both horrifies and threatens. As Krook, the "Chancellor," dies, the only thing that remains is Lady Jane, the threatening female presence. To some extent, Lady Jane becomes the ultimate Medusa. She is the Mrs. Jellyby and the Lady Dedlock who cannot be destroyed or silenced by the patriarchal world. It is also interesting to note, however, that though she can screech and wail, Lady Jane cannot speak. In addition, Krook, and perhaps symbolically though his association, Chancery, is illiterate. Though he is fascinated by words and documents, he cannot read. Mrs. Jellyby, though she is literate, wastes her words on vanity and false charity, and Lady Dedlock who is effectively silenced through her shame for the majority of the novel, is ultimately silenced through her death. In addition, Sir Leiscester and the male narrator are also silent at the end of the novel. Both the decayed patriarchy and the transgressive 
maternal fade to confusion and silence at the end of Bleak House, and the only voice that remains is Esther's voice, a voice that is still filled with possibility. 


\section{CHAPTER TWO}

Black Ink and Black Fog: The Maternal Other

Two central structures of male power in Bleak House are the city of London and the Court of Chancery, and both of these structures are connected to dominating, patriarchal presences. The Court of Chancery is ruled by the seemingly all-powerful Lord High Chancellor, and, in the novel, London seems dominated by the seemingly allpowerful third person narrator of Bleak House. As the Chancellor sits in judgment over the Court and the people who are forced to bend to his will, the third-person narrator's masculine voice seems to judge not only London and the Court of Chancery, but also the people who are swallowed up by the oppressive constructions that surround them.

Through their connection to the structures of the Court and London, the Chancellor and the Narrator become entwined in two dominant symbols prevalent throughout Bleak House, black ink and black fog. Black ink is simultaneously the ink of the court documents that make up the legal machine that runs Chancery and the ink of the Narrator's voice, printed and re-printed across the page. The black fog is both described by the ink through the printed word of the Narrator's voice, and enmeshed in the ink as it surrounds and envelopes all the people of London, including the Chancellor himself who sits at the heart of the fog:

Fog everywhere. Fog up the river, where it flows among green aits and meadows; fog down the river, where it rolls refilled among the tiers of shipping, and the waterside pollutions of a great (and dirty) city. Fog on the Essex marshes, fog on the Kentish heights. Fog creeping into the cabooses of collier-brigs; fog lying out on the yards, and hovering in the rigging of great ships; fog drooping on the 
gunwales of barges and small boats. Fog in the eyes and throats of ancient Greenwich pensioners, wheezing by the firesides of their wards; fog in the stem and bowl of the afternoon pipe of the wrathful skipper, down in his close cabin; fog cruelly pinching the toes and fingers of his shivering little "prentince boy on deck. Chance people on the bridges peeping over the parapets into a nether sky of fog, with fog all around them, as if they were up in a balloon, and hanging in the misty clouds...Never can there come fog too thick, never can there come mud and mire too deep, to assort with the groping and floundering condition which this High Court of Chancery, most pestilent of hoary sinners, holds, this day, in the sight of heaven and earth (Dickens 17-18). ${ }^{8}$

The image of Chancery and the High Chancellor as patriarchal symbols of corruption and oppression in the midst of a black pervasive fog enveloping the inhabitants of the city represents the entrapping power of the repressive structures that must somehow be overcome in order for the inhabitants of London to fly free. The question is what can combat the black fog and ink that have enveloped the city and the people? Perhaps in answer to this question, two characters emerge from the dense ink and fog of the text, Lady Dedlock and Esther Summerson. Through their connection to the court case, Jarndyce and Jarndyce, Esther and Lady Dedlock are trapped under the constructions that surround Chancery and the High Chancellor. As women, Esther and her mother are also repressed by societal structures and patriarchal oppression. They become feminine and maternal others in contrast to the dominant patriarchy of their society, and as maternal

\footnotetext{
${ }^{8}$ It is interesting to note here that the smoke that fills London is also a sign of industry. Dr. Heidi Scott points out that Dickens's intent to point out its uselessness perhaps naively also infers that the "inverse, a pastoral 'blank and clear,' would indicate the dissolution of the Empire and its productions."
} 
others, they have the potential to rise up in contrast and opposition to the dense fog and the black ink that dominate and constrain society.

As the double protagonists of Bleak House, Lady Dedlock and Esther become the focus of the plot and structure of the novel. Though the court case Jarndyce and Jarndyce is the centerpiece of the novel, the action of Bleak House revolves around these two women and their maternal connections, both to each other and to other characters. In some respects, Lady Dedlock and Esther divide the novel into two parts. The first part, told by the third person male narrator, is Lady Dedlock's story. The narrator speaks of Lady Dedlock and the others who are connected to her story in an unrelenting present tense as though he must be a constant presence in their story. The narrator's voice tends to be obtrusive and judgmental, always looking down at the characters from above, but never connecting to the characters with either sympathy or compassion. Lady Dedlock is never allowed to narrate her own story. Instead, she must always be narrated about. In this way, Lady Dedlock becomes the ultimate repressed maternal other.

Lady Dedlock, who gives birth to a child out of wedlock, loses her maternal identity as she loses the infant that she believes died when it is born. Although readers eventually learn that Esther Summerson is Lady Dedlock's natural child, neither Esther nor Lady Dedlock knows of the other's existence, and Lady Dedlock is introduced in Bleak House as "My Lady Dedlock (who is childless)" (Dickens 24), and thus the "omniscient" narrator lies or is mistaken, revealing that his omniscience is fallible. Lady Dedlock is falsely represented in Bleak House as childless, cold and sterile, and she is connected to the death and stagnation that surrounds her home, Chesney Wold. Even her name 'Dedlock' must remind the reader of the words 'dead' and 'lock' as though Lady 
Dedlock is locked in death. Lady Dedlock says that "she has been 'bored to death,"” and she is described as falling into a "freezing mood" (Dickens 24-25). Lady Dedlock's husband, Sir Leicester, is much older than she, and "he will never see sixty-five again, nor perhaps sixty-six, nor yet sixty seven. He has a twist of the gout now and then, and walks a little stiffly" (Dickens 25). Sir Leicester is a decrepit old man, significantly older than his wife, and her marriage to him contributes to her barren, frozen and stagnant life. Sir Leicester is also connected to the male narrator in that he is a dominating patriarchal figure in the novel through his ancient lineage, his role as the head of his household, and his insistence on old values and traditions. Sir Leicester believes that people should remain within their own spheres and that they dare not venture out of the roles that nature and society have constructed. Though Lady Dedlock has her own sexual past, her marriage to an apparently desexualized, patriarchal old man and her frozen, deathlike character make her appear desexualized and oppressed. In this way, Lady Dedlock becomes a type of double character. She is a woman who is simultaneously living and dead, sexualized and unsexualized. She is a mother who has no child. She is a mother who is not a mother.

Lady Dedlock is a mother who has never mothered or nurtured a child, but her daughter, Esther Summerson, though she has no natural children, is portrayed in Bleak House as a maternal figure. Also, as the second narrator of Bleak House, Esther can be seen in contrast to the male, third person narrator. In direct opposition to the male narrator, Esther speaks her narration in the first person, and in the past tense. She tells her own story. Unlike the presumed male narrator, Esther's voice is personal, intimate, and in many ways maternal, though she herself never knew her own mother. Despite the 
absence of a loving mother and nurturing environment, Esther spends her life caring for everyone around her. Even as a young girl in boarding school Esther was responsible for the care of other children: "I was not only instructed in everything that was taught at Greenleaf, but was very soon engaged in helping to instruct others" (Dickens 39). As an adult, Esther continues to progress from one maternal role to another, from her role as companion to Ada Claire to her encounter with the neglected Jellyby family, in which Esther immediately steps into the void left by the careless Mrs. Jellyby and tries to care for her poorly-mothered children. Ada, commenting on Esther's care of the Jellyby children, says: "Esther was their friend directly. Esther nursed them, coaxed them to sleep, washed and dressed them, told them stories, kept them quiet, bought them keepsakes..." (Dickens 77). Because of her motherly attitudes and responsibilities, Esther recalls that she was called: "Old Woman, and Little Old Woman, and Cobweb, and Mrs. Shipton ${ }^{9}$, and Mother Hubbard, and Dame Durden ${ }^{10}$, and so many names of that sort, that my own name soon became quite lost among them" (Dickens 107). In Death and the Mother from Dickens to Freud, Carolyn Dever argues that, "even in her role as housekeeper, Esther's identity is mythologized, multiplied; as the 'good little woman of our lives"' (91). Esther's own name is lost in her identity as a mother, and she becomes a constructed mythos of multiple good or legendary mothers. Esther epitomizes what Joan Manheimer calls the "Good Mother - noble, nurturing, necessary - hover(ing) over all strata of Victorian England" (530). Esther becomes, in the novel, a construction of an ideal mother. She is a virgin mother. She is the Victorian ideal of a nurturing, noble

\footnotetext{
${ }^{9}$ Mrs. Shipton was a legendary English witch who was also known as Mother Shipton.

${ }^{10}$ Dame Durden was a notable housewife from an English song.
} 
mother who would never choose anything or anyone over her own children because motherhood is her only identity. In this way, Esther is doubly othered. For her role as a woman in a patriarchal society she is already othered by her position as a woman. She is the other of man. She is also othered from her own identity. She is not so much Esther Summerson as she is a housekeeper, Cobweb, Little Old Woman, and all of the other othered identities and roles that she assumes as she mothers everyone around her. At this moment in the novel, Esther becomes an extreme example of the stereotypical, Victorian good mother and angel of the house, and she fulfills the ultimate, constructed expectation of motherhood.

Ironically, Esther, the idealized mother, has no knowledge of her own mother for the first half of the novel. Commenting on her desire for her mother, Esther says: "I had never heard my mama spoken of. I had never heard of my papa either, but I felt more interested about my mama. I had never worn a black frock, that I could recollect. I had never been shown my mama's grave" (Dickens 31). Although Esther assumes that her mother is dead, she cannot remember ever mourning for her. Esther's maternal connection seems bound up, not in her mother's presence and life, but in her mother's absence and death, and therefore in the landscape of her own fantasy and perception.

The initial severing of Esther's connection to her mother comes about because Esther's aunt's perception of her mother's sexuality as transgressive causes her to withhold both her own love and Esther's mother's identity and potential nurturing love. When Esther was born, her aunt told Lady Dedlock that her child had died. Esther's aunt then took Esther away to raise her herself in secret as her godmother. When Esther, as a young child, begs her godmother/aunt for an explanation of her origin, Esther remembers 
that, "she raised me, sat in her chair, and standing me before her, said, slowly, in a cold, low voice - I see her knitted brow, and pointed finger: 'Your mother, Esther, is your disgrace, and you were hers"' (Dickens 32). As a child, Esther both longs for her mother and feels that she and her mother were somehow connected in mutual shame, extending into each other in the moment when they caused each other a disgrace so terrible that it forced a rift and separation between them. Esther's and her mother's mutual sexual shame is perhaps one of the causes of their frozen sexuality. Lady Dedlock hides her sexuality behind a mask of shame and despair, and her daughter can never become a sexualized woman while she remains tethered to her mother's sexual identity. Lady Dedlock succumbs to the aim of Victorian sexual politics, limiting the woman's sphere to the shame of her transgression, and Esther, because she remains connected to her mother's shame, becomes complicit in her mother's transgression. Dickens's treatment of Esther's complicity, however, becomes problematic since she is portrayed as a good and innocent character in the novel. It seems that Dickens is demonstrating that Esther's supposed complicity in Lady Dedlock's transgression is a matter of perception. Dickens reveals that Esther is only stained by Lady Dedlock's sin because of the politics of Victorian society constructed around her.

Esther is connected to Lady Dedlock, not only through the circumstances of her birth, but also through her resemblance to her mother. Esther and Lady Dedlock's uncanny resemblance is first revealed in the novel through the portrait of Lady Dedlock that hangs in Chesney Wold. The portrait is itself, as a picture, an image or double of Lady Dedlock, but, because Esther physically resembles her mother, it also becomes a double of Esther. Since Esther physically resembles the mother she has never met, the 
portrait becomes the reader's first clue into the connection and relationship between Esther and Lady Dedlock. Mr. Guppy, the law clerk who has noticed and admired Esther several times in the novel, comes on business to Chesney Wold. While he is there, Guppy is struck by the portrait of Lady Dedlock and "he stares at it with uncommon interest; he seems to be fixed and fascinated by it" (98). In response, Rosa, a housemaid, says that it is Lady Dedlock's portrait, and "It is considered a perfect likeness" (98). Guppy, though he has never seen Lady Dedlock, insists, "Yet I know her...if it ain’t very curious how well I know that picture...if I don't think I must have had a dream of that picture, you know!” (99). Guppy's obsession with Esther and his fixation on the portrait of Lady Dedlock become a clue for the reader who begins to conflate Esther with Lady Dedlock. Although the relationship between Esther and her mother is not fully revealed, she and Lady Dedlock draw closer together in the reader's mind.

In addition to a bond of sexual shame and physical resemblance, Esther and Lady Dedlock are connected through maternal desire. Esther longs for the mother that she never knew. In her article "Mothers and Daughters," Marianne Hirsch quotes psychologist Carl Jung in that "Every mother contains her daughter within herself, and every daughter her mother...Every woman extends backwards into her mother and forwards into her daughter" (qtd. Hirsch 209). Jung's idea exposes a psychological and physical phenomenon in which mothers and their children, boys as well as girls, are biologically connected because the mother once contained her child within her own body, while her child simultaneously contains the mother through their shared genetics. The connection between mother and daughter becomes more complicated by the fact that the daughter also extends forward into her own potential children. In this way, every mother 
is also a daughter and every daughter is also a potential mother. Esther and Lady Dedlock, through their nature as mother and daughter, share a link that binds them together, and though they have never met they are drawn together through this physical and psychological bond.

The mother-daughter bond that Esther and Lady Dedlock share can also be seen in the desire of the child to return to the maternal embrace. The desire for the maternal embrace is particularly applicable to Esther, who as a child has never known her mother, and necessarily longs for what Julia Kristeva calls the desire or attempt to "restore the lost primordial connection with the mother" (qtd. Moore 2). Esther, the good little mother of Bleak House, manifests her desire to return to the protective maternal embrace by becoming the maternal caretaker of her environment. Esther figuratively searches throughout the novel for the "lost" mother and the maternal embrace that she never experienced by nurturing and caring for those around her. On one hand, Esther and Lady Dedlock, as Jung suggests, are connected through the biological and psychological bond that binds mother to daughter and daughter to mother. Esther and her mother are forces that will not be separated, and every action and event in the novel brings them closer together. The longing for the maternal embrace becomes evident just before Esther is about to be re-united with her mother. As Lady Dedlock approaches Esther, Esther is rendered motionless, "as by a something in her face that I had pined for and dreamed of when I was a little child; something I had never seen in any face; something I had never seen in hers before" (Dickens 483). On the other hand, Esther's search for the lost maternal embrace can never be realized. According to Kristeva's theory, though the child searches for the lost connection with his or her mother [Kristeva extends this to all 
children and parents], "the 'lost' object cannot be restored" (qtd. Moore 2). Esther can never re-experience the primordial connection with her mother that she was denied at birth. Because of her desire to connect to her mother, and the subsequent frustration of that desire, Esther's identity becomes bound up in her mother. In other words, Esther becomes the "other" of Lady Dedlock through the bond that connects them as mother and daughter through their shared desire for the lost maternal embrace that can never be restored and they each become one part of a complete maternal character. Lady Dedlock longs for the impossible embrace of the child she believes is dead while Esther simultaneously longs for the primordial connection to the mother she has never known. Throughout the novel, this simultaneous longing and inability to connect drives both Lady Dedlock and Esther forward until they are finally united, not in the primordial connection of birth, but as a mature mother and daughter. When Lady Dedlock reveals herself as Esther's mother, Esther remembers:

I looked at her; but I could not see her, I could not hear her, I could not draw my breath. The beating of my heart was so violent and wild, that I felt as if my life were breaking from me. But when she caught me to her breast, kissed me, wept over me, compassioned me, and called me back to myself; when she fell down on her knees and cried to me, 'O my child, my child, I am your wicked and unhappy mother! O try to forgive me!' -...I tried to tell her - that if it were for me, her child, under any circumstances to take upon me to forgive her, I did it, and had done it, many, many years (Dickens 483-484).

When Esther is finally embraced by her mother, she is able to experience the maternal love that had been denied her, and she is able to begin to move toward her own sexual 
identity, an identity that would eventually lead to her own marriage and sexual freedom. However, soon after they first embrace, Lady Dedlock pulls back from Esther, "My child, my child'...'For the last time! These kisses for the last time! These arms upon my neck for the last time! We shall meet no more" (Dickens 486). Lady Dedlock loses her own daughter a second time. The second time, however, she chooses to give Esther up to protect herself, her husband and the Dedlock name. At this point it seems that Dickens has offered a solution to the perception that the sexually transgressive mother must die for the daughter to be free. For a brief moment, the power of her own fate is in Lady Dedlock's hands and the reader is left to wonder, if she had not pulled back, if she had instead fully embraced Esther as her daughter, would she have still been doomed to die? Perhaps in partial answer to this question, at the end of the novel, the reader obtains insight into Sir Leicester's ultimate reaction to the knowledge of Lady Dedlock's transgression - "Full forgiveness" (Dickens 712).

Since Lady Dedlock continues to remain bound up in her own sexual shame, Esther must continue to fulfill her role as the unsexualized other and opposite image of her own mother. As a character who ultimately survives and moves past her constructed roles, however, Esther confounds and eventually subverts her own seemingly prescribed destiny as a perpetual virgin mother. Esther's contradictory role throughout the novel as a good housekeeper and virgin mother is never more apparent than when she first arrives at Bleak House and a maid brings her a bunch of keys: "The housekeeping keys, miss...I was told to bring them as soon as you was alone, miss" (Dickens 80 ). From her very first moment at Bleak House, Esther's role is defined; she is not the wife or mistress of the house, instead she is to be the keeper of the house, and in that role, the unsexualized 
mother of all its inhabitants. Esther herself says: “'Esther, Esther, Esther! Duty, my dear!' And (I) gave my little basket of housekeeping keys such a shake, that they sounded like little bells, and rang me hopefully to bed" (Dickens 92). The symbolism of Esther's keys further serves to represent her double identity as a simultaneously powerful and powerless woman. On one hand, her keys are "symbols of the authority of the housekeeper, and they become emblems of the order and security needed in the bleak house of England" (Pritchard 448). However, keys are also "symbols of imprisonment or entrapment" (Pritchard 449), and Esther, though she has authority, is also imprisoned by that same authority and a duty to others that she cannot escape. The dichotomy between Esther's authority and power symbolized by the keys and her simultaneous entrapment by the same keys is made more puzzling and paradoxical because of her cheerful and hopeful attitude. Esther's duty fills her with confident optimism and she seems oddly unaware that she could have or even want any identity other than her role as the housekeeper and "mother" of Bleak House.

The double role of Esther's keys becomes even more significant in light of the symbolic association of a woman's womb, or maternal sexualized space, with a prison. ${ }^{11}$ If the sexualized space becomes something dark and dangerous, something undesired, the keys that a woman holds have a power to imprison or free whom she imprisons within the dark maternal space. However, since Esther is unsexualized, her womb is not dark or dangerous and her keys become less threatening to the patriarchal world view. Esther is a

\footnotetext{
${ }^{11}$ The association of the womb with a prison is noted by Philip Weinstein in his analysis of William Faulkner's The Sound and the Fury. In The Sound and the Fury, Quentin thinks, "The dungeon was Mother herself" (440), and his brother Jason paws at his mother's skirts revealing in her pocket, "its cache of hideous keys like a grotesque parody of the children who should instead have come forth from her womb. And indeed her womb is terrifying - a space imaged here as rusted, iron, a jailor's fortress..." (434).
} 
maternal other. She is both the other of her own mother and the other of herself. She is a mirror image that reflects back a self that is not the same, for when the Esther who jingles her keys with authority looks in the mirror, the figure staring back at her is the other who is trapped by those same keys. Thus Esther's duality is further revealed as an identity that is both restricted and unbound. In other words, Esther's keys become a symbol of her imprisonment in patriarchal constraints and her simultaneous power within the system.

Esther's character is particularly puzzling because she is herself a paradoxical character. While it cannot be denied that in many ways Esther is forced into restrictive roles, she can also be seen as a much more complex character. One of the ways in which Esther's complexity is revealed is through her role as an idealized virgin mother and her connection to what has become known as the cult of the Virgin Mother. The cult of the Virgin Mother celebrates the image of an ideal type of mother that follows from the Virgin Mary and has been the center of discourse for hundreds of years. The image of the Virgin Mary becomes itself a paradoxical symbol. The Virgin Mary's own lack of sexuality makes her an image of unsexualized motherhood that is impossible for other women to attain. In addition, the Virgin Mary is also a symbol of the self-sacrificial woman, always willing to put others ahead of herself. Susan Moore notes that while the idea of the mother as a self-sacrificing woman may appear desirable, empowering and heroic, there is a cost as women's experiences remain in the private sphere of the home (Moore 2). The heroic and self-sacrificial becomes paralyzing because the woman has sacrificed her identity and agency to the point that she has narrowed her sphere of power and influence to the confined boundaries of the home. In many ways Esther becomes this 
type of heroic figure, constantly sacrificing herself and her own identity to take care of others, and it is through her sacrifice that Esther remains powerless and confined to her limited role. The Virgin Mary, however, though she is unsexualized and self-sacrificing, is still a powerful image that reaches well beyond the confines of her own seeming limitations. The image of the Virgin Mother reveals that Esther, as a type of virgin mother, becomes a symbol of the simultaneous power and powerlessness of women. Another aspect of the cult of the Virgin Mother presents her as the symbol of a silent mother. Philip Weinstein notes that in "Stabat Mater" Julia Kristeva explores the "myth" of the Virgin Mary and "reads the Virgin as a figure of speechless succor" (436). Esther, however, is not speechless. In direct opposition to Kristeva's claims about the role of the Virgin Mother, Esther becomes a speaking subject. Also, though the Virgin Mary herself can be viewed as speechless, she also has a powerful voice that can be heard in and through the prayers of those who have prayed to her for generations for strength, comfort, or help. Like the Virgin Mother, Esther also becomes a paradoxical voice, and through the combination of her constructed, unsexualized maternal role and her narrative voice, Esther simultaneously affirms and subverts the patriarchal expectations of the maternal role of women in Victorian society.

Of the three divine components of what Weinstein terms the Virgin Mary model succor, virginity and silence (already seen as problematic) - Esther appears to retain the two ideals of virginity and succor while simultaneously betraying the ideal of silence. Esther is a virginal nurturer who has the power to speak and tell her own story. Esther's ability to break free from the fetters of the constructed ideal Virgin Mother or Angel of the House is perhaps demonstrative of Dickens's own partial deconstruction of the very 
model of womanhood that he also seems to affirm. According to Kristeva, "male-coded scripting of maternal desire" attempts to construct a maternal pattern where the mother's desire is "speechlessly satisfied through the suckling of her son" (Weinstein 437). Instead, Kristeva calls for a revision of this male-coded scripting, and in this revision, the mother's desire becomes conflicted, tension-filled, and heard as sound rather than silence (437).

In Bleak House, silence itself becomes an enemy that can injure and even destroy. In her article "Language Couples in Bleak House," Dona Budd argues that Esther's godmother/aunt, Miss Barbary, in a "travesty of the submissively quiet Victorian woman," keeps quiet about Esther's origin as the daughter of her sister, and this silence “is part of her [Miss Barbary's] obsession with her sister's sexual transgression, which becomes the deforming principle of her existence as much as it is for Lady Dedlock and threatens to be for Esther" (209). Like her sister, Lady Dedlock is also twisted by her own silence about her lover and the subsequent birth of her daughter. Lady Dedlock eventually destroys herself rather than face the consequences of her own sexuality, and it is her silence and fear of her husband's denunciation and society's condemnation that eventually drive her to her death. As Lady Dedlock and her sister are deformed by silence, Esther derives power from her speaking voice, not, as Budd suggests, a voice "recruited and absorbed into a patriarchal agenda" (217), but a voice that derives power from its maternal agency.

Themes of doubling and multiplicity run throughout Bleak House. Esther's multiple maternal names, her connection as a double to her own mother, and her role as a maternal other can also be seen in the double narration of the novel. Esther also becomes 
the other narrator. In one sense Esther is the maternal narrator in opposition to the masculine, paternal third person narrator of Bleak House. The masculine voice of the novel takes on the role of the omniscient narrator while Esther, the feminine voice, appears to have significantly less power in the telling of her own limited perspective. Esther's narration is different from the more masculine, self assured third-person narrator as she is often self-deprecating and unsure. The first time her voice is heard in the novel, Esther says: "I have a great deal of difficulty in beginning to write my portion of these pages, for I know I am not clever” (30). Although Esther speaks her own narrative it can be argued that her identity is lost in the names that others give her, and that because she often undermines her own narrative through her self-deprecating voice, Esther's voice becomes lost in the male dominated voice of the third- person narrator. Some critics of the novel find Dickens's use of Esther's narrative a mistake that weakens the overall effect of the story. According to Merritt Moseley, "From the beginning there have been objections to Esther... Though young women similar to Esther had featured again and again in Dickens... and though a narrator who functioned like Esther had appeared in David Copperfield; somehow letting Esther narrate the novel and occupy the central position has always grated on critics" (37). ${ }^{12}$ It is interesting to note, especially given Moseley's comparison of Esther with David Copperfield, the acceptance of David Copperfield, a male narrator, as opposed to Esther, a female narrator. Although Esther's voice may appear weak and self-deprecating, she still has a voice. Also, the very fact that

\footnotetext{
${ }^{12}$ Moseley notes that Dickens's "friend and literary advisor John Forster concluded that the attempt to do what Dickens did in this novel was 'a difficult enterprise, full of hazard in any case, not worth success, and certainly not successful' (II: 113), and George Gissing was equally unimpressed (139)" (37). Moseley does mentioned several critics who defended the dual narration including Albert Guerard, M.E. Grenander, and Peter E. Garrett (37).
} 
Dickens chose to give Esther a voice is significant and emphasizes Esther's power as a speaking subject. As a maternal figure, Esther's authority, though perhaps weak and confined, must be heard, and Esther, who has the ability to speak, and to give voice to her own story, is able to push against the male narrator to claim some power of her own. As a maternal other Esther's own nurturing and self-sacrificial actions and voice gain power because her narration contrasts with the male narrator's omniscient, judgmental tone. In a way, Esther becomes a balm that sooths the "rough beast," the megalosaurus who stomps and roars his way throughout Bleak House. Like the keys at her waist, Esther's maternal narration has both the power of authority and the power to entrap. According to Paul de Man "We assume that life produces the autobiography as an act produces consequences, but can we not suggest, with equal justice, that the autobiographical project may itself produce and determine the life..." (qtd. Dever 86). Obviously Esther's life, since it is fictionalized, cannot produce her autobiography, and so it is her autobiography that must produce her life. However, the question is, does the fact of her narration alone give her a voice apart from her creation as an ideal mother? Is she simply the weaker, maternal other of the more powerful male narrator? Is her autobiography simply the trace, the black ink, recording the remnant of a life that is constructed by a male narrator's voice and the world in which she lives? I argue that Esther's is not just the trace or echo of a seemingly more powerful male narrator, and it is in fact her maternal voice that not only enables her to survive to speak but to combat the often negative implications of black ink in the novel.

Black ink is an important image and theme in Bleak House. In one sense, as a written text, the pages of Bleak House are themselves covered in black ink. However, 
within the ink of the text, there are also other images of ink and writing. The wills and thousands of court documents in the case of Jarndyce and Jarndyce are themselves examples of the massive amount of ink that is spilled in the novel. Letter writing is also an important activity and perhaps atrocity in Bleak House, and several characters use up large amounts of black ink in the composition of many different types of letters. The type of ink used in the mid $19^{\text {th }}$ century was stored in a bottle, and the writer had to dip his or her pen into the ink in order to write, thus making it not only easy to literally blot or spill the black ink all over the pages of text, but also making it impossible for writers to avoid staining their hands with ink. Michael Ragussis argues that the stain of ink can be identified in this novel with the stains of blood and the stain of intercourse: "The stain is at once a point of origin (the stain of the love letters, the father-writer's stain of procreation) and an end point (the stain of Hawdon's grave, the stain of Lady Dedlock's shame that forces her into this same grave, the stain of blood on Tulkinghorn's floor)" (265). ${ }^{13}$ A couple of points can be drawn from Ragussis' observation about the conflation of ink, blood, and intercourse. First, since blood and intercourse are both related to the body, an ink that relates to blood and sex becomes an ink of the body. However, thinking again about the maternal female body, blood stains can also be associated with a woman's menstrual cycle and fertility as well as the blood that comes with birth and thus blood and ink can have a positive connotation in a feminist reading. Luce Irigaray argues that the blood of a woman's menstrual cycle can be threatening to certain male or phallic fantasies about a woman's body, particularly the fantasy of the

\footnotetext{
${ }^{13}$ After Tulkinghorn is murdered by Lady Dedlock's maid, he is found lying next to a pool of blood on the floor. "So, it shall happen surely, through many years to come, that ghostly stories shall be told of the stain upon the floor, so easy to be covered, so hard to be got out" (Dickens 624).
} 
virginal mother. Commenting on Irigaray’s argument, Jane Gallop says, "In phallic fantasy, the solid-closed-virginal body is opened with violence; and blood flows. The fluid here signifies defloration, wound as proof of penetration...menstrual blood is not a wound in the closure of the body; the menstrual flow ignores the distinction virgin/deflowered" (qtd. Weinstein 438). In this way, menstrual blood disrupts the fantasy of male domination through penetration and wounding because the blood flows without the phallic presence.

The idea of a stain also has a negative connotation as something to be avoided or something that corrupts the purity of something else. The negative perception of staining is particularly interesting in Bleak House since both Lady Dedlock and Esther are "stained" by the fact that Esther was born out of wedlock. Looking at ink as the stain of a woman's body then makes the black ink in Bleak House a type of paradox. On one hand, the stains of blood from the woman's body are absolutely necessary for the reproduction of life and the continuation of generation. On the other hand however, the blood is seen as somehow corrupting and shameful. The idea of menstrual blood as stain or shame is also associated with the "sin" of Eve. According to the Christian tradition, since the fall of Adam and Eve in Genesis, all people have become sinners whose punishment is death, so, if all women breed sinners who must die, the womb becomes not only a place of life, but also a place of death. In his play Waiting for Godot, Samuel Beckett explicates this image of birth and death: "They give birth astride of a grave, the light gleams an instant, then it's night once more" (103). From the moment life is conceived, it is already moving toward death. Beckett's image provides an eerie insight into this duality of a woman's fecundity. A woman's womb is necessary for the continuation of generation, 
but it is also the same space that begins the inevitable journey toward death. The conflation of the stain of ink with the stain of blood confounds the narration as both the male narrator and the male writer must symbolically enter into the woman's menstrual stain in order to be born, just as there is no way to write without using ink

As a corrective to the negative implications of stain, ink and blood, we may examine Helene Cixous's theories of ecriture feminine and the power of the female body in writing. One of the interesting things about the theory of ecriture as developed by Jacques Derrida is that it finds no hierarchical difference between speech and writing. Since, for Derrida and other deconstructionists, there is always a lag or gap between a sign and its meaning, no form of communication, whether speech or writing, can ever catch up to itself and obtain any kind of pure meaning (Of Grammatology). According to Derridian theory, writing becomes just as powerful as speech and vice versa, and both writing and speech are always equally deferred through language. Since people think in language, even thoughts themselves become separated from meaning as the mind uses language to filter and understand experiences. Through the mind, the body itself takes an active role in the way people perceive and communicate their own experiences of the world around them. Cixous and other feminist theorists argue further that discourse has, for hundreds of years, been man centered or phallocentric. In phallocentric discourse, woman is defined by what she lacks rather than what she has, for example, Sigmund Freud's theory of castration defines a woman as not having a penis. Cixous wants to undo this kind of thinking and she calls for women to exert the power of their own bodies in writing: "Woman must write her self...Woman must put herself into the text...Writing is for you, you are for you; your body is yours, take it" (Cixous 1942- 
1943). Cixous calls for women to seize the occasion to speak, "shattering entry into history, which has always been based on her suppression" (1947). ${ }^{14}$ Thinking again about Esther as a narrator, a teller of her own story, we find that while Esther obviously continues to operate in a phallocentric world, she is still beginning to speak. Her voice is small and timid, and her body is unsexualilzed and repressed, but she can still be heard. As we contrast Esther with the strong, confident voice of the male narrator, her timid, self-deprecating voice becomes almost a resistance to the dominating forces around her.

With Esther as a maternal figure in Bleak House, Esther's voice becomes a type of a mother's voice speaking out in the novel. As mentioned before, Esther fulfills the role of the good mother in her relations with the other characters in the novel, and, as a woman, she has something of the mother within herself apart from her maternal role. Cixous explains:

Even if phallic mystification has generally contaminated good relationships, a woman is never far from "mother" (I mean outside her role functions: the "mother" as nonname and as source of goods). There is always within her at least a little of that good mother's milk. She writes in white ink. (1948) For Cixous, mother becomes a metaphor for both the connection and community of the other and for the power of a woman's voice. It is particularly interesting that Cixous associates this kind of female writing with white ink, an ink that symbolically flows directly from the breast of the mother. It is also interesting that this white ink is present even in the midst of phallic mystification, or, perhaps, phallic power. In this way, though Esther is the creation of a male author, as a woman narrator she still has the possibility of

\footnotetext{
${ }^{14}$ Italics in original
} 
writing with the white ink of the mother. In other words, Esther's use of ink as a female narrator contrasts with the theme of black ink that runs through the novel, not only through the male narrator's perspective, but also through the novel's other characters and, paradoxically, the work of the author.

Esther's own father, who Esther also believes is dead, makes his living in the novel as a law-writer who uses black ink to copy legal documents. As a copier, Esther's father, who calls himself Nemo (or no one), loses his agency and identity as he spills black ink in the mechanical act of copying and reproducing the words of others. Although she is a woman, Caddy Jellyby also uses the black ink that she is covered with to take dictation from her mother, Mrs. Jellyby. Like Nemo, Caddy uses the black ink to copy or reproduce the words of another, and Caddy resents that she is forced to write her mother's words, over and over again, in a mindless parody of creation. Both Caddy and Nemo become, in the novel, living typewriters, mere instruments that use ink to produce the thoughts of others. Caddy's use of black ink is especially ironic since it is her own mother, who should have shared with her the bond of mother's milk, the white ink, who forces her into her black inky role. As a female narrator, Esther is not forced like Caddy into a black inky role, nor is she condemned like Nemo to continuously reproduce the words of another. If Esther's voice were indistinguishable from the male narrator's, her narration would become submerged in his. Instead, Esther's voice is maternal and radically different from the masculine narration and so Esther is able to use her maternal "white ink," her female voice and agency, to narrate her story.

In contrast to the white ink that Cixous imagines, the image of black ink becomes a symbol of the darkness that seems to cover the spaces around Bleak House. Esther's 
father, Nemo the law writer, copies documents from the court case, Jarndyce and Jarndyce, which has been going on for generations and has piled up thousands upon thousands of documents and copies of documents, all written in black ink. One of the documents that Nemo copies finds its way to Chesney Wold, the Dedlock estate, and when, by chance, Lady Dedlock sees it, she recognizes the handwriting and swoons. Lady Dedlock nearly faints because she recognizes the handwriting on the document as that of her former lover, Captain Hawdon, but her "faintness of death" is also a symbol of the death-like state she has inhabited since the "deaths" of Hawdon and her child, and it is a premonition of the literal death she will suffer because of the writing she has just seen. Both the black ink that covers the thousands of documents of Jarndyce and Jarndyce and the black ink that covers this single copy of one such document, usher in the events that lead to death and tragedy in Bleak House. As a court case in the High Court of Chancery, Jarndyce and Jarndyce becomes a manifestation of the darkness that covers the Chancery Court and all of London. Bleak House begins: "London....mud in the streets...crust upon crust of mud...Fog everywhere..." (Dickens 17). The London of Bleak House is a dark, decaying and diseased place that becomes a sort of evil maternal other. In addition to a symbolically masculine, patriarchal space, London also becomes like a dark mother who poisons her children, and gives them black ink instead of white milk. In Bleak House, London becomes the bleakest of mothers, and women like Lady Dedlock cannot survive the muddy, inky world that is constructed around them.

As opposed to Lady Dedlock, Esther, as an ideal good mother, is in direct opposition to the dark womb of London that she inhabits. In "The Ghostly Signs of Bleak House," Michael Ragussis compares Esther with Christ, and instead of a "sun" 
who stands in contrast to the dark mud and fog of London, Esther becomes "the Son who is to save us from the letter...Esther stands as the new covenant, superseding the wilderness marked with a rain of ink" (272-273). Seeing Esther as the savior of Bleak House is problematic at best, given Esther's failure to save others including Richard and Jo, but Ragussis' view of Esther as a figure that must stand in opposition to the blackness that surrounds her positions Esther as perhaps the only mother who is able to combat, by her very survival as an unsexualized mother, the darkness that surrounds her. Also, Esther is both the "sun" and the daughter. The conflation of the sun with the Son and Esther's position as a woman gives further credence to her power in Bleak House. She is the daughter who is also the sun/Son. Esther contrasts with both the dark, foggy and poisonous space that is London and the black ink that stains the people and the pages of Bleak House. Esther Summerson is, by the very nature of her name, the summer, or the sun that shines in the dark places of Bleak House. Although she may not have an identity of her own until she is able to move past her unsexual roles and into her own marriage, as Esther fulfills her role as an ideal mother, she cares for and brings light to everyone around her. Esther is also, at least in some measure, able to move past the mechanical reproduction of another's thoughts. She is not subjected to the male narrator, but she is able to write in her own maternal style, a white ink that nurtures and sooths, bringing light in opposition to the darkness of the patriarchal narration.

As a figure that combats the black ink and black fog of Bleak House, Esther becomes a type of maternal other, writing in white ink despite being trapped in a phallocentric world. At the end of the novel, Esther responds to her husband's compliment about her beauty: “'And don't you know that you are prettier than you ever 
were?' I did not know that; I am not certain that I know it now" (Dickens 816-817). The fact that Esther still seems self-deprecating and painfully modest causes some critics to argue against her power as a narrator. Carolyn Dever, commenting of Esther's modest protestations at the end of the novel, says 'if 'Esther' is the putative subject here, then the novel ends on a note of bald manipulation in the guise of false modesty...If it is 'Dickens' who controls the end, however, the novel concludes with a commentary on, and thus an appropriation of, the terms of Esther's empowerment as a narrator" (102103). Dona Budd also notes that Esther's voice has been appropriated by her male creator. However Budd argues that "The strategy [of appropriation] calculated to make Esther invisible thrusts her unavoidably, like a lopped limb, onto our attention. Hers is the voice that scholars and reviewers get most agitated about, the one we most notice. In trying to squash her voice into a deferential whisper, Esther produces a screech" (215). According to Budd, Esther's false modesty becomes a manipulation; not her own manipulation, but that of the author himself, who reveals in her narration patriarchy's the "painful and deforming effects," of appropriating female voice (Budd 220). In Budd's view, if as a narrator, Esther's voice is appropriated by her creator, she obtains a kind of narrative agency through that appropriation in that she reveals the danger of appropriating female voice.

I argue, however, that, though Esther may reveal the danger of male appropriation, her narration also resists appropriation. Instead, Esther's voice contrasts with and ultimately survives the destruction of patriarchy in the novel. As Esther fulfills the role in Bleak House of the good mother, the stereotypical patriarchal figure of the book becomes Sir Leicester Dedlock, Lady Dedlock's husband. At the end of the novel, 
when Sir Leicester discovers Lady Dedlock's secret and realizes that she has run away, he falls to the ground:

He fell down, this morning, a handsome stately gentleman; somewhat infirm, but of a fine presence, and with a well-filled face. He lies upon his bed, an aged man with sunken cheeks, the decrepit shadow of himself...he had so long been thoroughly persuaded of the weight and import to mankind of any word he said...but now he can only whisper; and what he whispers sounds like what it is mere jumble and jargon (Dickens 711).

Dona Budd notes that there is a connection in Bleak House between Sir Leicester and the anonymous narrator. "The close of the Anonymous Narrator's narrative, however, which pictures Sir Leicester's dotage, calls attention to the narrator's relation to male failure. The last words of the assertive, assured male narrator describe the collapsed patriarch, failed in spirit and voice" (Budd 216). As Sir Leicester's voice ends in a jumbled whisper, the narrator's last words are of Sir Leicester's continued infirmity and the decay of Chesney Wold. The patriarchal narration concludes, "passion and pride, even to the stranger's eye, have died away from the place in Lincolnshire, and yielded it to dull repose" (Dickens 813). Budd's observation that the male narrator's voice ends with the description of Sir Leicester's failing body, mind and spirit and Sir Leicester's own inability to speak at the end of the novel is particularly telling of Esther's power in the novel. Also, the narrator's last words in Bleak House, "dull repose," give the reader a picture, not only of Sir Leicester's own inactivity, but also the inability of the patriarchal narration to move forward and continue. Thus to move on from Budd, if the male narrator can be associated with Sir Leicester as a dying, pathetic voice, then at the end of 
the novel, it is not Esther whose voice is timid because Esther's narration continues arter the male narrator has stopped. The patriarchal narrator, who began the novel speaking with strength and authority, boldly stroking his black ink across the page, ends in a whisper, fading out behind the white ink of Esther's female voice. 


\section{CHAPTER THREE}

The Ghost in the Mirror: Esther's Fragmented and Multiplied Identity

As an unsexual, good figure in Bleak House, Esther counters the negativity of the threatening or bad mothers in the novel. She is not fated to die like Lady Dedlock, she does not neglect her children like Mrs. Jellyby, and she is not doomed to madness like Lady Jane. In many ways, Esther represents a type of "canny" remedy to the uncanny people and spaces in Bleak House. Esther's canniness, however, puts her in a complex and problematic position in the novel. On one hand, Esther's ability to combat the dark evils of Bleak House reveals her power in the novel as a force of resistance against Chancery, poverty and neglect. On the other hand, the only way that Esther can resist is by conforming to many of the patriarchal conventions that seem to severely limit a woman's power and agency. Although Esther ruptures the power of the male narrator through her voice, she also seems to resist feminine agency through her inability to break certain societal structures.

In this chapter, however, I will argue that although Esther, to some extent, remains trapped in the patriarchal construction of her society, and although she is in some respects a "canny" figure, she also operates simultaneously in the novel as an uncanny presence. It is her dual nature as both canny and uncanny that makes Esther's identity fragmented and complex, and it is in the spaces within her fragmentation that Esther attains agency and possibility. In many ways, Esther resists wholeness, and through that resistance, Esther's character begins to interrogate identity itself because she can never be identified as either one identity or another. Instead, Esther demonstrates an identity that is itself uncanny and unfixed. Ironically, however, Esther is also moving toward her own 
home. She is the home-maker in Bleak House, and in the end, she obtains a fixed home of her own while still retaining her fragmented identity.

Uncanny identity is further revealed in themes of homelessness in Bleak House. The state of being without a home, or of being unfixed and wandering, results in negative consequences for many of Dickens's characters. There are several characters without "homes" in Bleak House, including the wards in Jarndyce and Jarndyce, Richard, Ada and Miss Flite; Nemo, Esther's father; Charley and her family; the orphan Jo, and Esther herself. With the exception of Jo, all of these characters have some kind of residence, but none of them really have homes. The wards in Jarndyce and Jarndyce have been displaced by the court case and Miss Flite is forced into her tomb-like room in Krook's shop while Ada and Richard come under the protection of John Jarndyce. Eventually Richard and Ada both leave John Jarndyce and Bleak House and live together in rented rooms. Like Miss Flite's room, however, this space is more of a waiting room than a home, and, eventually, it becomes Richard's tomb. Nemo, who is a wanderer, lives in a cadaver-like state in Krook's shop until his death, and poor little Jo lives on the street, forced to move from place to place until illness also takes his young life. Esther is made homeless when she is taken from her mother as a baby and made to live with her aunt. Although her aunt provided the necessities of a home, shelter and food, since she did not give Esther acceptance and love, her house was cold and empty. Perhaps the closest place to a home that Esther experiences is Bleak House. However, since Esther is forced to remain the "housekeeper" of Bleak House, she can never really call it her home.

One of the themes that connect many of the homeless characters in Bleak House is the idea of waiting. Miss Flite and Richard wait for judgment, Ada waits for Richard, Jo 
waits until he must move along again, and Nemo waits for death. The concept of waiting leads to a type of stagnation or, especially for Jo, the idea of moving toward nowhere. As the narrator tries to crawl into Jo's mind he imagines that Jo thinks:

...what does it all mean, and if it means anything to anybody, how comes it that it means nothing to me? To be hustled, and jostled, and moved on; and really to feel that it would appear to be perfectly true that I have no business, here, or there, or anywhere; and yet to be perplexed by the consideration that I am here somehow, too, and everybody overlooked me until I became the creature that I am! It must be a strange state, not merely to be told that I am scarcely human...but to feel it of my own knowledge all my life! (222-223).

As a homeless wanderer, Jo is in a state of constantly moving on while existing in a kind of perpetual limbo, being not one thing or another but being between things. David Plotkin argues that “Jo's existence is uncanny because it is both strange and familiar, almost too familiar. The novel highlights the fact that, while Jo is a part of everyday London life, he seems to belong to a radically different place" (27). Jo believes that he is both human and not human, that he is both here and not here, and that he both is and is not. In many ways, Jo is forced to become, like Nemo, a type of no one who is always in a state of waiting, but never arriving.

In the novel, Esther shares a precarious position with characters like Nemo and Jo. In some ways she, like them, has been overlooked, and as a "bastard" child, she has also been shoved aside by society. In addition, like the other homeless characters in Bleak House, Esther is also in a type of limbo or waiting space. She is an unsexualized housekeeper with no home of her own, and one of the questions in the novel is whether 
Esther will ever arrive at a realization of her own identity, or if she will be perpetually stuck in her constructed roles. The question of Esther's fate in Bleak House comes to a crisis when her benefactor, John Jarndyce proposes marriage. Because of her gratitude for his kindness and her genuine affection for him, Esther agrees to the marriage. The reader, however, is left to wonder at Esther's choice. Though Jarndyce is not bad or evil, he is an older man, and his role is Esther's life had always been as a guardian or father figure. The idea of a marriage between Esther and her guardian becomes reminiscent of the marriage of Lady Dedlock and Sir Liecester, and seems to threaten Esther with the same stagnant, decaying life that Lady Dedlock endured. As the wife of John Jarndyce, Esther would become stuck in her own limbo or waiting space where she would perpetually be the "Little Old Woman," old before her time and trapped in a space without possibility. The reader is also faced with the incestual connotations of Esther's possible union with Jarndyce, and forced to contemplate her unsexuality juxtaposed with possibly transgressive sexual practices. At the end of the novel, however, Esther is released from her promise of marriage to John Jarndyce and she marries instead the young doctor, Alan Woodcourt. Although her marriage to Woodcourt may seem like the exchange of one man for another, the fact that she is able to move away from her mother's fate and to marriage with an attractive young man whom she loves opens up new possibilities.

Maria Tatar argues that Esther is homeless in Bleak House because of her veiled origin. According to Tatar, "Homelessness becomes the badge of her obscure origins" (180), and Esther can 'turn her attention to the future and live comfortably in the 'canny' world of domestic virtue only when she is 'at home' with her identity" (181). For Tatar, 
Bleak House presents a picture of what she calls "radical homelessness" (182); a situation where the stability of the world is shattered and the world becomes hostile and uncanny. Once Esther's origin is revealed and embraced, Esther is able, in Tatar's opinion, to "transform the sinister habitation...into the secure haven of a home" (182). Although the idea that Esther is able to fully be "at home" with her own identity is problematic, Esther's broken relationship with her mother and the hidden nature of her origin must be revealed for Esther to move beyond the "homelessness" of her own situation. David Plotkin notes that in Bleak House, Esther is described as a woman who could "make a home out of [any] house" (23), and he argues that "by the end of the novel we see that her ability to make a home through keeping house signifies a larger transformation that is necessary: turning the strange, sometimes savage, nation into a familiar homeland" (23). Plotkin's observation points to a paradox about Esther. She is herself somehow homeless, but in her homelessness, she simultaneously transforms houses into homes and strange, dangerous spaces into the familiar and safe. In contrast, Mrs. Jelllyby, because of her obsession with a strange, "savage" land, turns her home into something both strange and savage.

Although Esther continues to sooth the savage homes in Bleak House, she is also made strange and even ghostly through her relationship to her mother's identity. Carolyn Dever argues that Esther and her mother are engaged, in the novel, in a power struggle "to the death about which one of them has the agency to shape the terms of the text" (86). The idea of Esther in a life and death struggle with her mother becomes particularly interesting in light of Esther's two possible endings in the novel. On one hand, if she marries John Jarndyce, she becomes doomed to remain in an "unsexualized," stagnant 
existence like her mother. On the other hand, if she marries Woodcourt, she opens up the possibility for a new kind of life. The struggle of Esther and Lady Dedlock then becomes a struggle for Esther's release from her bond with her mother and her mother's deathlike, frozen fate. Dever continues, "Lady Dedlock, for example, is textually manufactured as dead not just once, but twice, before she actually appears as dead. The same is true for Esther, in the sense that she is persistently represented as dead ${ }^{15}$ before she is able to articulate herself as not only living, but powerful" (86). Because of her hidden and broken connection to her mother, Esther becomes an uncanny character since, like many of the other uncanny characters in Bleak House including Lady Dedlock, Jo, Nemo and even Krook, Esther is simultaneously living and dead. Dever says, "From birth, Esther has been the unwitting participant in a fiction in which she played the role of a corpse, a dead baby, as well as an alternative fiction (the one reported in the text) in which she played an orphan" (85). For much of the novel, Esther and her mother both believe that the other is dead. Esther then participates in the falsehood that she herself is dead, just as Lady Dedlock participates in the fiction as Esther's dead mother. Esther's symbolic death is best represented in her childhood doll. When Esther leaves her godmother/aunt's house for the last time, she remembers: "I had wrapped the dear old doll in her own shawl, and quietly laid her - I am half ashamed to tell it - it the gardenearth, under the tree that shaded my old window" (Dickens 37). Esther's burial of her doll is a chilling representation of Esther's own mother symbolically burying Esther herself after Esther's fictional death. In this sense, Esther buries herself. Esther is now the dead doll - she is her mother's dead baby. But Esther's doll is more than just a

\footnotetext{
${ }^{15}$ This can be seen in part in Lady Dedlock's perception of Esther as a dead baby.
} 
representation of Esther herself. The doll is also Esther's child, and she is the first baby that Esther cares for and nurtures. As Esther buries her doll, she also buries her own maternity. Esther, as an unsexualized mother, is not a potential agent of generation, and any identity other than her identity as an ideal mother is lost as she lowers herself and her sexual motherhood into the ground with her dead doll.

Despite her narrative role, Esther becomes, in Bleak House, a character of absence. She is missing, not only the knowledge of her mother, Lady Dedlock, but also her own maternal identity. As Esther plays the role of her own corpse in the novel, she becomes the ghost of her own narration. Marjorie Garber writes, "And what is a ghost? It is a memory trace. It is the sign of something missing, something omitted, something undone" (299). In Lacan's theory of the veiled phallus, all signification is veiled by language, and thus the phallus is itself already a ghost because the real phallus cannot be seen except in its shadowy form. As a woman, Esther becomes a symbol of a double absence. As a woman, she is the absent phallus, the physical reminder that all signification is only trace, and as a ghost, she is the trace of her own life. By burying herself in the ground, Esther reveals that all identity is, in this sense, already veiled. Esther is the ghost of a ghost; she is a piece of a broken mirror that continually reflects image after image of othered identity while never revealing the true nature of self.

Paul de Man, looking at prosopopoeia ${ }^{16}$ as "the fiction of the voice-from-beyondthe-grave," says: "It is the figure of prosopopoeia, the fiction of an apostrophe to an absent, deceased, or voiceless entity, which posits the possibility of the latter's reply, and confers upon it the power of speech." De Man continues, looking at two lines of Milton's

\footnotetext{
${ }^{16} \mathrm{~A}$ figure of speech in which an absent or imagined person is represented as speaking.
} 
sonnet "On Shakespeare" (Then thou our fancy of itself bereaving/Dost make us marble with too much conceiving): the phrase "dost make us marble...cannot fail to evoke the latent threat that inhabits prosopopoeia, namely that by making the dead speak, the symmetrical structure of the trope implies, by the same token, that the living are struck dumb, frozen in their own death" (qtd. Garber 305-306). As a narrator, Esther speaks, but if she is a ghostly presence, she is also a ghost who speaks. Esther, as a speaking absence, becomes like a Medusa, freezing the living and striking them dumb "in their own death." However, who are the living in Bleak House? If the dead can be compared to the non-transgressive characters, the characters who do not threaten the established order like Esther or John Jarndyce, or the transgressive characters who threaten but are destroyed like Lady Dedlock, Nemo, and Jo, then the living who are struck dumb by the medusa could be the Sir Leicesters, the Chancellors, and the other patriarchal symbols of the novel.

As a ghostly presence in Bleak House, Esther is also connected to the ghost who haunts Chesney Wold. The ghost that walks at Chesney Wold is never seen or heard by the characters in Bleak House, but it is a presence whose specter is felt throughout the novel. "While Esther sleeps, and while Esther wakes, it is still wet weather down at the place in Lincolnshire. The rain is ever falling, drip, drip, drip, by day and night, upon the broad flagged terrace-pavement, The Ghost's Walk” (Dickens 92). Both Lady Dedlock and Esther are connected to the Ghost of Chesney Wold through the picture of Lady Dedlock that hangs in the drawing room. Immediately after he sees the portrait and reveals the first conflation in the novel of Esther and Lady Dedlock, Mr. Guppy is told the story of the Ghost of Chesney Wold. In the legend, one of the Dedlock ancestors, Sir 
Morbury Dedlock, led a troubled life with his wife, and one night, as she was sabotaging his horses, Sir Morbury seized her and she was lamed "in the hip, and from that hour began to pine away" (Dickens 100). From that moment, the lady never spoke to her husband again, and she was seen, day by day, dragging herself along the terrace until one day she dropped and spoke her final words to her husband: "I will die here where I have walked. And I will walk here, though I am in my grave. I will walk here, until the pride of this house is humbled. And when calamity, or when disgrace is coming to it, let the Dedlocks listen for my step!"(Dickens 101). It is significant that the ghost of Chesney Wold is a woman, destroyed through the violence and oppression of a man. It is also significant to note that the ghost becomes dual presence in Bleak House since she is a transgressive woman who, though she died as a result of her transgression, continues through her presence in the novel as a ghost. The dead woman will never be forgotten as long as her story is remembered and told. Esther's connection with the ghost imbues her with some of that same power. During the course of the novel, though the ghost does not speak, her footsteps are heard echoing on the terrace, and in the echoing footsteps of the murdered ghost, perhaps the dead do speak and the living are struck dumb, "frozen in their own death." Esther's voice becomes like the footsteps of the ghost, refusing to be silenced, and echoing through the pages of Bleak House.

Esther is not only connected to the ghost of Chesney Wold through her physical connection with Lady Dedlock and her role as a woman, in some sense, she also becomes the ghost that threatens the Dedlock family. Christopher Herbert argues that because of Esther's aunt's “original-sin theology" Esther becomes complicit (at least in her own 
mind) in her mother's sexual guilt. Herbert notes Esther's own acknowledgement of this guilt:

"I felt," Esther says, "as if the blame and the shame were all in me, and the visitation had come down" (XXXVI.453). This magical (that is, pathological) transfer of guilt has an uncanniness that is entirely in keeping with the large argument of Bleak House and that is made explicit in the episode of Esther's nocturnal visit to Chesney Wold. She finds herself prowling along the Ghost's Walk, and in a moment of hallucinatory panic that fills her, she says, with "a terror of myself," undergoes another fantastic transfer: she recognizes herself as the ghastly Dedlock specter, the very image of guilt and disgrace (XXXVI.454) (110).

Esther becomes in her own mind the Ghost that haunts the Dedlock family through her own conflation of herself with her mother's sexual transgression. In another way, Esther also becomes the Ghost of Chesney Wold through her unwilling complicity in the ruin of the Dedlocks through the shame that would fulfill the Ghost's prophecy. Esther's complicity comes about because, through no fault of her own, Esther is the physical result of Lady Dedlock's shame, and so she silently haunts the Dedlocks because her very presence in the world threatens their ruin.

Lady Dedlock, both as Esther's mother and as the frozen trace of her own ghostly existence, is revealed as an image in a broken mirror. When Esther first sees her mother sitting in church, though she does not yet know who she is, Esther recalls, "something quickened within me, associated with the lonely days at my godmother's; yes, away even to the days when I had stood on tiptoe to dress myself at my little glass, after dressing my 
doll. And this, although I had never seen this lady's face before in all my life - I was quite sure of it - absolutely certain... But why her face should be, in a confused way, like a broken glass to me, in which I saw scraps of old remembrances...I could not think" (Dickens 250). Upon seeing her mother for the first time, Esther remembers looking in her own mirror as a child, and in that mirror, Esther sees not only her own face, but also the faces of both her doll, who she dresses as a mother would her own child, and her mother. Esther, her mother, and her doll are all reflected in the same mirror, and in that reflection, Esther is, at the same time, both mother and daughter. The image in the mirror can also reflect "the illusory sameness of mother and daughter" (Michie 202). Because Esther physically resembles her mother, when she sees Lady Dedlock, she remembers her own reflection as she saw it in the mirror as a child, and through that reflection, "the two women merge into a single identity" (Michie 201). This reflection is, however, only an image, and as an image it is again a trace, a ghostly likeness of Esther both as a mother and as "being like" her own mother. Esther's conflated reflection is further complicated because the image, or the face of the mother, is also to Esther, "like broken glass," and as glass breaks it reflects, not one image, but multiple images or multiple identities that cannot be reconstructed. According to Michie, "both the novel and Esther resist a reconstruction of the mirror" (202). Esther's identity as a mother is broken and fragmented because her own mother's identity has been hidden or veiled from her. The multiple maternal identities that Esther manifests in the novel - - Dame Durden, Mother Hubbard, Mrs. Shipton, Little old Woman, and Cobweb, among others - - can be traced back to the broken shards of her maternal identity. Esther becomes the other within mother, but, because the other is, for Esther, broken glass, she must continue to reflect the 
multiple identities of the idealized mother she has never known. The broken reflection of identity is further complicated since, by its nature, a reflection is only a trace. Michie notes that, according to Lacan ${ }^{17}$, the mirror, "offers to the infant a conception of self (that) is by its very nature illusory, unstable, and dependant on lack, absence and difference. The mirror can never produce a totalized self (202). When Esther looks at her maternal reflection in the imagined broken mirror, she can only see multiple, fragmented identities that are, themselves, traces or ghosts of self.

Throughout the first half of the novel, Esther and Lady Dedlock remain veiled or separated from each other. When Esther's existence is finally revealed to her mother, Lady Dedlock cries, "O my child, my child! Not dead in the first hours of her life, as my cruel sister told me; but sternly nurtured by her, after she had renounced me and my name! O my child, O my child!” (Dickens 395). For the first time, Lady Dedlock appears to come to life as she is momentarily unfrozen from her former stagnation and realizes that she is, in fact, a mother. At possibly the same moment that Lady Dedlock discovers that her daughter is alive, Esther has a premonition that something has changed or will change within herself: "I had no thought, that night - none, I am quite sure - of what was soon to happen to me. But I have always remembered it since, that when we had stopped at the garden-gate to look up at the sky, and when we went upon our way, I had for a moment an undefinable impression of myself as being something different from

\footnotetext{
${ }^{17}$ For Lacan, the mirror stage is the founding moment of Imagination where the infant first recognizes his image in the mirror. The child identifies with the imagined "whole" image in the reflection. This image, however, is only a reflection that can never be attained. For Lacan, the Other becomes the mirror image, the counterpart, and the other person, and so the something that is missing from the Other is something that was never there because it is only a reflection of the other's gaze, and is therefore a presence that is simultaneously an absence.
} 
what I then was" (Dickens 411). Physically, the event that Esther foresees is the illness she will contract from her maid Charley and the young boy Jo, after she and Charley, in another example of unselfish, virtuous motherhood, care for Jo when he appears at Bleak House, ravaged by a mysterious sickness. Through this illness, Esther almost dies and almost becomes, literally, the dead baby that she and her mother "bury." Although Esther survives her illness, she is scarred to the point that she is unrecognizable.

Many critics view Esther's illness as her turning point in the novel. She has, after all, had a premonition that something within her would change. Also, disease and illness are often transforming moments, especially when those illnesses bring the sufferers close to death. Helena Michie notes that, according to Jane Gallop, "the illusory sameness of mother and daughter cripples the development of the daughter" (202). For Michie, the illusory image that Esther sees in the broken mirror, the image of "sameness" to her mother, is itself the image that cripples her development and her identity. According to Michie, Esther's illness and resulting disfigurement become a "point in her text where a self begins to emerge" (202). Esther, by becoming physically different from her mother, can begin to find her own identity apart from her identity as the "good mother." However, this view does not account for the fact that, although Esther, through her illness, does begin to view herself differently, she still remains an unsexualized housekeeper figure in the novel. In fact, through her scars, Esther becomes even more unsexualized as she loses her physical appeal, and believes that, if she ever were beautiful, she is no longer. Upon viewing her face in the mirror, which had been absent from her room throughout her illness, Esther says, "I was very much changed - O very, very much...I had never been a beauty, and had never before thought myself one; but I 
had been very different from this. It was all gone now...I had kept Mr. Woodcourt's flowers...I was doubtful whether I had a right to preserve what he had sent to one so different...I treasured them only as a remembrance of what was irrevocably past and gone" (Dickens 478). At this point, the flowers that Esther keeps, a gift from her potential admirer, Allan Woodcourt, become the last reminder of any potential sexuality Esther may have had. Until she is reunited with Alan at the end of the novel, Esther believes that she can never marry the man she loves. Through the transformation of her illness, Esther now fully yet incorrectly believes and accepts her limited identity as the housekeeper and unsexualized good mother. Carolyn Dever believes that Esther's scars serve not as a rebirth, but as a defacement that further desexualizes her and "allows her to perform more precisely the moralistic role of 'Good Esther," a hard-working, non-sexual woman" (100). It is also possible that Esther's disfigurement symbolizes the revelation of Lady Dedlock's shame. Esther physically displays the symbolic scars of her mother's sexual transgression. The scarring, however, becomes a blameless disfigurement since Esther is innocent. ${ }^{18}$ Perhaps this sense of innocence is furthered by the fact that after their marriage, Woodcourt does not see Esther's scars as scars but as a part of her beauty.

Paul Pickrel argues that Esther's illness transforms her in that it separates her from her mother by removing the resemblance between them. Pickrel notes: "Before her illness her remarkable resemblance to her mother has defined her as Lady Dedlock's illegitimate daughter, but after her illness her smallpox scars make her simply Esther Summerson, her own woman" (86-87). According to Pickrel, Esther's lack of identity comes from her shame as her mother's illegitimate daughter, and through her symbolic

\footnotetext{
${ }^{18}$ I attribute this insight to Dr. Heidi Scott.
} 
separation from her mother, Esther, according to Pickrel, can now embrace her identity as "her own woman." Esther herself seems to lend credence to Pickrel's argument when she says, "I was so changed as that I never could disgrace her by any trace of likeness" (Dickens 484). Esther's words, however, reveal that she is not, as Pickrel argued, concerned with her own shame as the illegitimate daughter, but she is instead concerned with Lady Dedlock's shame as a woman who was an unwed mother. Instead of revealing that she now has her own identity, Esther instead continues to reveal herself as the ideal mother, who "mothers" her own mother and forgives her fully. Esther is concerned only with Lady Dedlock's protection and happiness, and through this desire to nurture and protect Lady Dedlock, Esther now becomes the 'mother' of her own mother. Carolyn Dever allows, with Pickrel, that Esther's physical defacement frees her from the shame of physically resembling her mother, but she argues further that Esther's encounter with her mother, rather than freeing Esther fully, results in a second abandonment and a solidification of Esther's symbolic death. Commenting on Esther's reunion with her mother, Dever says:

It is at this point that Lady Dedlock reveals to Esther that she is her mother, begs forgiveness for her sins - then leaves her newfound child forever. After this scene, Esther is left with only a letter, the trace of their encounter. Esther reports, "She put into my hands a letter she had written for my reading only; and said, when I had read it, and destroyed it - but not so much for her sake, since she asked nothing, as for her husband's and my own - I must forevermore consider her as dead" (566).... when Lady Dedlock asks her (Esther) to consider her dead, 
she asks to repeat in fictional terms the very thing that Esther has feared as a truth throughout her life (83).

Esther has always feared and believed that her mother was dead. Now her mother is revealed to her, but instead of allowing Esther the rebirth that would have come in the arms of her mother, Lady Dedlock abandons Esther again and forces her to destroy the letter, the only trace of their encounter. Dever sees Esther as "an agent of forgiveness," but as Esther is left "standing on the Ghost's Walk at Chesney Wold, [she] is at this moment established as a ghostly presence, a living absence, within her own autobiography" (84). As a ghost however, Esther, like the echoing footsteps of the Ghost of Chesney Wold, is still a presence that refuses to fade away.

If Lady Dedlock's first letter to Esther as the trace of their encounter further solidifies the veil between mother and daughter then her second letter to Esther becomes the trace that will result in both the lifting of the veil and the severing of the maternal bond. When Lady Dedlock flees Chesney Wold because her sexual transgressions have been revealed, she writes Esther a final letter. The letter is the second and last letter that Esther will ever receive from her mother, and where the first letter reveals Esther's ghostly presence in her own narrative, the second letter spurs Esther forward to stop her mother from literally becoming a ghost. Lady Dedlock writes to her daughter: "I have no purpose but to die...It was right that all that had sustained me should give way at once, and that I should die of terror and my conscience...I shall be soon forgotten...Forgive" (Dickens 753). Lady Dedlock now has identity and purpose, and she is moving rapidly toward something that she desires - death. Esther also now has purpose as she goes out into the night to stop her mother from dying. At this point in the novel, Esther becomes 
more than just the construction of an ideal mother. Esther has a mission and goal, and she goes forward until, at the graveyard where her father is buried, she sees a figure who she describes as "lying on the step, the mother of the dead child" (Dickens 756). Esther believes, at first, that the figure on the step is Jenny, the young mother of a dead baby whose body Esther cared for by laying her own handkerchief, monogrammed with her name, over the face of the dead child. Dever calls Esther's handkerchief "a veil, simultaneously marking and masking the plurality of 'Esther Summersons'...” and argues that "The handkerchief bears the traces of the dead baby, bears the signifier 'Esther Summerson'” (94). Esther's handkerchief symbolizes not only Esther's symbolic death in the novel, but also her lack of identity. Esther is masked by the construction of her ideal motherhood and her symbolic burial. Seeing Jenny, the mother of the dead baby who, through her handkerchief, bears her own name, Esther says, "I saw before me, on the step, the mother of the dead child" (Dickens 756). The dead mother on the step is now both Jenny and Lady Dedlock, and the dead child is both Jenny's dead baby and Esther. From Esther's own lips comes the confession that she herself is the dead child as she, mistaking her mother for Jenny, calls the dead woman "the mother of the dead child," or, in other words, the mother of herself as the symbolically dead child. Esther remembers: "I passed on to the gate, and stooped down. I lifted the heavy head, put the long dank hair aside, and turned the face. And it was my mother cold and dead" (Dickens 756). As Esther removes the veil that covers the face of the dead woman, revealing her own mother, the veil shrouding Esther as a dead child is also removed. Esther is now both revealed to her mother and separated from her mother in death. Esther is no longer the ghost of her mother's dead baby, and as her mother dies, she is 
able to rise from her symbolic grave and claim some measure of maternal identity. Instead of remaining the unsexualized housekeeper of Bleak House, Esther marries Allan Woodcourt and moves into her own "Bleak House" with her husband (Dickens 797-798). As the veil between Esther and her mother is lifted, Esther's scars also seem to vanish. Her husband Allan says, "My dear Dame Durden...do you ever look in the glass?...And don't you know that you are prettier than you ever were?" (816). Though Esther is not made wholly canny by her mother's death, she is able to symbolically rise up from the metaphoric grave and release her own ghostly presence. In a way, by burying her mother, Esther is able to unbury her doll and embrace her own potential maternal agency and sexuality.

Whether or not Esther fulfills her potential for identity and agency, however, is unknown. Though Esther exhibits some power and freedom as an individual, she still seems to operate within the construction of her character. Thinking of her guardian, John Jarndyce, Esther says: I have never lost my old names, nor has he lost his; nor do I ever, when he is with us, sit in any other place than in my old chair at his side. Dame Trot, Dame Durden, Little Woman! - all just the same as ever; and I answer, Yes, dear Guardian! Just the same" (815). Instead of becoming an individual, a single identity, Esther seems to have expanded her multiple identities to include her identity as a wife and mother while still retaining the ideal names and identities of her past. Esther is given a new home, but her home is still named "Bleak House," a name given to the house, not by her, but by her former guardian. Esther's house is also both old and new; it reaches into the future and at the same time it extends into the past. At the end of the novel, when Esther's husband comments on her beauty, Esther once again looks away from herself: 
"But I know that my dearest little pets are very pretty, and that my darling is very beautiful, and that my husband is very handsome, and that my guardian has the brightest and most benevolent face that ever was seen; and that they can very well do without much beauty in me - even supposing-" (817). As a character and a narrator, Esther retains the potential of agency and identity simply because she survives. Perhaps, in Bleak House, it is the potential that matters. If all identity is a mirror or construction, reflecting back potential identities, but never revealing a singular, static, fully realized identity, then Esther has agency, not as an individual, but as a woman who survives and moves forward. In Bleak House, it is Richard Carstone, the young ward of Jarndyce and Jarndyce, who looks for completion and finality. He compares his unsettled situation as a ward to an unfinished house: "If you lived in an unfinished house, you couldn't settle down to it; if you were condemned to leave everything you undertook, unfinished, you would find it hard to apply yourself to anything; and yet that's my unhappy case. I was born into this unfinished contention with all its chances and changes..." (Dickens 316 ). Richard wants a life that is stable and unchanging, but it is that obsession with completeness that eventually kills him. When Esther looks at Richard and his young love Ada, she sees them, "so young, so beautiful, so full of hope and promise, they went on lightly through the sunlight, as their own happy thoughts might then be traversing the years to come, and making them all years of brightness. So they passed away into the shadow, and were gone. It was only a burst of light that had been so radiant. The room darkened as they went out, and the sun was clouded over" (184). Esther sees in this moment the illusion or the reflection of happiness. Happiness is not guaranteed, it is instead another image in a broken mirror, one possibility of life among many. Perhaps 
because of her role as a narrator Esther is able to look back and see that everything changes, and everything moves, and it is in that movement or journey that the possibility of life and happiness resides. Esther, as a woman who survives and the narrator who continues, retains her identity and agency as one who journeys, and as a mother who ushers in a new generation of agency and change. 


\section{CONCLUSION}

The Birds' Flight

The world of Bleak House becomes a madness-inducing world, and the chief madness-inducing institution is the symbol of patriarchy and oppression, the Court of Chancery. Tom Jarndyce, who himself went mad and blew his own brains out, was known to tell people to "keep out of Chancery...it's being ground to bits in a slow mill; it's being roasted at a slow fire; its being stung to death by single bees; it's being drowned by drops; it's going mad by grains" (Dickens 66). Many characters in the novel go either completely or partially mad because of their association with Chancery, including Richard Carstone, Lady Dedlock, and even the cat, Lady Jane. However, perhaps the most memorable mad character in Bleak House is the little old lady, Miss Flite. Poor Miss Flite, who has been a ward of Chancery for so long that she has forgotten why she is there, waits only for judgment day - both the judgment of Chancery and the end of world as both seem almost synonymous in Bleak House.

As Miss Flite waits for judgment in her little room above Krook's shop, she keeps a collection of little birds in cages that represent everything and everyone who is trapped and caged by Chancery. The names of Miss Flite's birds reflect the descent of the mind from hope, through despair and into eventual madness and death, but the names also reflect Miss Flite's own descent as they themselves trail off into nonsense: "Hope, Joy, Youth, Peace, Rest, Life, Dust, Ahes, Waste, Want, Ruin, Despair, Madness, Death, Cunning, Folly, Words, Wigs, Rags, Sheepskin, Plunder, Precedent, Jargon, Gammon, and Spinach" (Dickens 203). Miss Flite says that she keeps the birds with the intention of setting them free when her judgment is given, but, she continues, "They die in prison 
though. Their lives, silly things, are so short in comparison with Chancery proceedings, that, one by one, the whole collection has died over and over again. I doubt, you know, whether one of these, though they are all young, will live to be free!” (Dickens 68).

Near the end of the novel, after Jarndyce and Jarndyce has ended, and right after Richard Carstone has died, Esther says, "When all was still, at a late hour, poor crazed Miss Flite came weeping to me, and told me she had given her birds their liberty" (808). It is unknown if Miss Flite set her birds free because Jarndyce and Jarndyce had in some sense been judged, or because Richard, a fellow ward of the court, had flown from life to his own eternal judgment, or because somehow Miss Flite felt she too had reached judgment or realized that it was pointless to keep waiting and finally allowed her own soul to fly free. Perhaps though, the flight of the birds also symbolizes a separation and release of the people they represent from the constraints of Chancery and by extension society. All of the birds, whether they are hope or beauty, ashes or waste, death or madness, are finally allowed to be free.

In many ways, Esther herself is like Miss Flite's birds, and she is perhaps one of the only "birds" in Bleak House to retain and even reclaim hope and beauty. Esther is not doomed to madness or death like Nemo, Jo, Lady Dedlock, Richard, and even Miss Flite herself, and her life has not descended into ashes or waste. Esther loses her beauty to the ravages of illness, but her beauty is also returned to her. She might have become trapped in a circle of freezing stagnation, but she is saved from marriage to her guardian, and is able to move beyond her identity as a Virgin Mother. It might be argued that since Esther still retains many of the multiple facets of her fragmented identity, and since she does marry and move into her own "Bleak House," that she, unlike Lady Dedlock and Richard 
who free into death, is still trapped in her own, albeit gilded, cage. Although, for Dickens, marriage is not necessarily restraining or entrapping, and a marriage of equals, like the one he writes between Esther and Alan Woodcourt, opens up more than it encloses. It seems that although Esther's freedom can be seen as limited, she still attains freedom in that she overcomes the dark, evil world that surrounds her and she survives and becomes a sexualized mother in the future.

In the end, it is Esther's voice that continues. After all the characters have gone silent, and the male, patriarchal narrator has faded away, Esther continues to speak as she opens up space for new possibility, generation and change. At the end of Bleak House, Esther's voice does not end, instead the novel finishes with Esther speaking, "even supposing---.“ (817). Everything about this final line speaks to continuation. The dash represents everything that can and will follow, and the word "supposing" leads the reader to suppose all of the different possibilities that Esther and her world could become. The dash also represents the continuation of Esther's voice because as the pages of the book close, the reader imagines that Esther continues to speak. And thus, as Miss Flite's birds fly upward, perhaps Esther, in her own way, really does fly free. 


\section{BIBLIOGRAPHY}

"A Mother to Her Daughter, Just on the Point of Marriage." The Ladies Monthly Museum (1804): 96-98. Print.

Beckett, Samuel. Waiting for Godot. New York: Grove Press, 1954. Print.

Brantlinger, Patrick. Rule of Darkness: British Literature and Imperialism, 1830-1914. Ithaca: Cornell University Press, 1988. Print.

Budd, Dona. "Language Couples in Bleak House."Nineteenth-Century Literature, Vol. 49, No. 2 (1994): 196-220. Print.

Cixous, Helene. "The Laugh of the Medusa." The Norton Anthology of Theory and Criticism Second Edition. Ed. Vincent B. Leitch et al. New York: W.W. Norton and Company, 2010. Print.

Derrida, Jacques. "From Of Grammatology." The Norton Anthology of Theory and Criticism Second Edition. Ed. Vincent B. Leitch et al. New York: W.W. Norton and Company, 2010. Print.

Dever, Carolyn. Death and the Mother from Dickens to Freud. New York: Cambridge University Press, 1998. Print.

Dickens, Charles. Bleak House. New York: Barnes and Noble Classics, 2005. Print.

Freud, Sigmund. "From The 'Uncanny."' The Norton Anthology of Theory and Criticism Second Edition. Ed. Vincent B. Leitch et al. New York: W.W. Norton and Company, 2010. Print.

Garber, Marjorie. "Hamlet: Giving Up the Ghost." Hamlet. ed. Susanne Wofford. New York: Bedford/St. Martin's. 1994. Print.

Herbert, Christopher. "The Occult in 'Bleak House." NOVEL: A Forum on Fiction, Vol. 17, No. 2 (1984): 101-115. Print.

Hirsch, Marianne. "Mothers and Daughters."Signs, Vol. 7, No. 1 (1981): 200-222. Print.

Holway, Tatiana M. Endnotes. Bleak House. By Charles Dickens. New York: Barnes and Noble Classics, 2005. 823-865. Print.

Jarosz, Lucy. "Constructing the Dark Continent: Metaphor as Geographic Representation of Africa." Georgrafiska Annaler. Series B, Human Geography, Vol. 74, No. 2 (1992):

105-115. Print.

Lacan, Jacques. "The Mirror Stage as Formative of the Function of the I as Revealed in Psychoanalytic Experience." The Norton Anthology of Theory and Criticism Second Edition. Ed. Vincent B. Leitch et al. New York: W.W. Norton and Company, 2010. Print. 
Lacan, Jacques. "The Signification of the Phallus." The Norton Anthology of Theory and Criticism Second Edition. Ed. Vincent B. Leitch et al. New York: W.W. Norton and Company, 2010. Print.

Lougy, Robert E. "Filth, Liminality, and Abjection in Charles Dickens's 'Bleak House."' ELH, Vol. 69, No. 2 (2002): 473-500. Print.

Manheimer, Joan. "Murderous Mothers: The Problem of Parenting in the Victorian Novel." Feminist Studies, Vol. 5, No. 4 (1979): 530-546. Print.

McLaughlin, Kevin. "Losing One's Place: Displacement and Domesticity in Dickens's Bleak House."MLN, Vol. 108, No. 5 (1993) 875-890. Print.

Michie, Helena. "Who is This in Pain?: Scarring, Disfigurement, and Female Identity in 'Bleak House' and 'Our Mutual Friend." NOVEL: A Forum on Fiction, Vol. 22, No. 2 (1989): 199-212. Print.

Moore, Susan Moore. "Kristeva, Ecocriticism, and the Cult of the Virgin." Diss. U of Calgary, 2006. Print.

Moseley, Merritt. "The Ontology of Esther's Narrative in 'Bleak House."' South Atlantic Review, Vol. 50, No. 2 (1985): 35-46. Print.

Pickrel, Paul. "Bleak House: The Emergence of Theme." Nineteenth-Century Literature, Vol. 42, No. 1 (1987): 73-96. Print.

Plotkin, David. "Home-Made Savages: Cultivating English Children in 'Bleak House.'” Pacific Coast Philology, Vol. 32, No. 1 (1997): 17-31. Print.

Pritchard, Allan. "The Urban Gothic of Bleak House."Nineteenth Century Literature Vol. 45, No.4 (1991) 432-452. Print.

Ragussis, Michael. "The Ghostly Signs of Bleak House."Nineteenth Century Fiction, Vol. 34, No. 3 (1979): 253-280. Print.

Suk, Jeannie. "Taking the Home." Law and Literature, Vol. 20, No. 3 (2008): 291-317. Print.

Tatar, Maria M. "The Houses of Fiction: Toward a Definition of the Uncanny." Comparative Literature, Vol. 33, No. 2 (1981): 167-182. Print.

Weinstein, Philip M. "'If I Could Say Mother': Construing the Unsayable About Faulknerian Maternity." The Sound and The Fury. Ed. David Minter. New York: W.W. Norton and Company, 1994. Print.

Zhang, John Z. "Uncanny American Fiction: Medusa's Face by Allan Gardner LloydSmith.” South Atlantic Review, Vol. 55, No. 3 (1990): 123-126. Print. 